\title{
HET ONTSTAAN VAN \\ HET VORSTENDOM VLAANDEREN ()
}

De moderne historiografie laat de geschiedenis van Vlaanderen ( $\left.{ }^{2}\right)$ nog beginnen met het opdagen van Boudewijn den Eerste. Dit traditioneele vertrekpunt wordt reeds in onze vroegste verhalende bronnen aangetroffen. In de elfde en twaalfde eeuw immers geloofde men algemeen dat Karel de Kale, koning van West-Francië, aan onzen eersten graaf, na zijn huwelijk met Judith, dochter van dezen koning, het gezag had toevertrouwd in het gebied tusschen Zee, Schelde en Canche, d. i. het latere vorstendom van Boudewijn's nazaten $\left({ }^{3}\right)$.

Zoo werd het ontstaan van het vorstendom verklaard De herkomst van Boudewijn zelf diende evenwel nog opgehelderd. Maar ook daarmee waren onze voorgangers niet verlegen!

(1) Ik druk hier mijn hartelijksten dank uit aan mijn vrienden $\mathbf{P h}$. Grierson, F. Blockmans, R. Tavernier en J. Blancquaert, alsmede aan prof. StrubBe, voor de hulp die ik van hen bij het schrijven van deze studie mocht ontvangen. Menige punten daaruit heb ik met hen besproken, en ze gaven mij talrijke nuttige wenken. Ook aun mijn meester, prof. F.-L. GaNsHOF, ben ik uiterst dankbaar voor de degelijke inleiding in de vroegste Vlaamsche geschiedenis die zijn licentiaatsoefeningen in de historische kritiek van het academisch jaar 1935-36, voor mij waren. Hij was ook zoo vriendelijk deze studie in handschrift te willen lezen en ik dank hem talrijke verbeteringen en interessante suggesties.

(2) Met Vlaanderen wordt in deze studie steeds het vorstendom van Arnulf den Goote bedoeld, d.i. het gebied tusschen Schelde, zee en Canche.

(3) Deze voorstelling wordt voor het eerst aangetroffen in de Translatio Sancti Wandregisili ", uit de tweede helft der $11^{\circ}$ eeuw : "Balduinus... accepta Judith, filia Karoli Calvi, universum regnum inter mare Gallicum et... Scaldem fluvium cum ea, Dei Gratia, sortitus est " (M.G.H. SS XV-2, blz. 627). 
Ze lazen in vroegere documenten dat een graaf Liederik en een graaf Ingelram hier te lande hadden geleefd, en dat de vader van Boudewijn den Eerste Audacer heette. Dat maar allemaal aaneengeregen en de genealogie van het Vlaamsch vorstenhuis was klaar! Liederik werd de stamvader van de dynastie, Ingelram zijn zoon, Audacer zijn kleinzoon, en Boudewijn zelf, de achterkleinzoon ( ${ }^{1}$ ). Deze gemakkelijke voorstelling vond ingang, doch werd weldra aangetast door een andere traaitie.

Te recht of ten onrechte geloofde men te Harelbeke, waar een kapittel in de eerste helft der elfde eeuw was opgericht $\left({ }^{2}\right)$, dat een zekere Liederik in de kerk begraven lag $\left({ }^{(3)}\right.$. Wanneer een monnik van Sint-Pieters te Gent omstreeks 1070 (*) ging verkondigen dat de vroegste gekende voorzaat van het heerschende vorstenhuis Liederik heette, aarzelde men te $\mathrm{Ha}$ relbeke niet, om dezen graaf met den ter plaatse begraven Liederik te vereenzelvigen. Het hoeft wel niet te worden gezegd, hoe de kanunniken van het sticht met deze ontdekking in hun schik waren! $Z i j$ waren het dus die het gebeente van den stamvader van't gravenhuis bewaarden! Wat een eer voor hun klooster! En welke schitterende vooruitzichten deed dit niet oprijzen! Er ontbrak echter nog iets aan hun geluk :

(1) Zie daarover mijn studie * De Forestiers van Vlaanderen ", in BuLLETIJN der Koninkijuke Commissie voor Geschiedenis, d. CV, 1940, blz. 282-305.

(2) Het kapittel werd inderdaad gesticht door Boudewijn den Vijfde (Bevestiging van deze oprichting in Prou, Recueil des Actes de Philippe Ior, Parijs, 1908, $n^{\mathrm{r}}$ XXV); anderzijds dagteekent de oudste oorkonde, waarin wordt gezinspeeld op het bestaan van het kapittel, van 1042 (uitgegeven door Ferrant, Esquisse historique sur le culte et les reliques de SaintBertulphe de Renty en l'église d'Harlebeke, blz. 63 (ANNALES DE LA socútít D'Emulation, $6^{\circ}$ reeks, d. I, 1898, blz. 1-219). Zie over dat document de kritische studie van SABBE (E.), Critische Studie over de oudste Oorkonden ban het Sint-Salvatorskapittel te Harelbeke, blz. 44-45 (in HANDELINGEN VAN het Genootschap... Société D'Émulation, d. LXXIX, 1936, blz. 30-58.) Daaruit volgt dat het Sint-Salvatorskapittel te Harelbeke moet zijn opgericht tusschen 1035 (sterftejaar van Boudewijn den IV॰) en 1042.

(3) Deze traditie bestond reeds circa 1070, zie mijn hooger vermeld artikel, blz. 293.

(4) Bij het opstellen van de Genealogia Bertiniana, die in deze jaren tot stand kwam, cf. mijn reeds vermelde studie, bl. 287. 
al had hij nog zoo roemrijke nazaten, Liederik zelf was toch geen vooraanstaand personnage geweest, 'n graaf van Harelbeke slechts! Daarin konden de vrome kanunikken niet berusten ! En ze zouden het daarbij niet laten!

Het valt immers op, hoe, de geheele twaalfde eeuw door, het onaanzienlijk figuur van Liederik - eigenlijk een in 836 gestorven gouwgraaf uit de omstreken van Sint-Omaars, waarover verder niets geweten is - aan luister wint : deze " graaf van Harelbeke " zou over geheel Vlaanderen hebben geheerscht (1), zou zelfs de eerste graaf van Vlaanderen zijn geweest (2) ! Deze laatste bewering druischte zoo hevig in tegen de gevestigde meening, dat ze niet kon worden gehandhaafd, maar veel werd er niet op afgedongen : wanneer de bezadigde Andreas Silvius, prior van Marchiennes, in 1194 het slotaccoord geeft, luidt het zoo: Liederik, en na hem Ingelram en Audacer, hebben over gansch Vlaanderen geheerscht, niet als graaf echter, doch als " forestier " of woudmeester van den koning van Frankrijk ( $\left.{ }^{3}\right)$. Dit vergelijk tusschen de traditioneele voorstelling en de Liederikslegende is een feitelijke overwinning van deze laatste. Dat het kanunniken van Harelbeke waren, die de Liederiksage hebben uitgedacht en verspreid, meenen we te hebben bewezen ( $\left.{ }^{4}\right)$.

Doorsponnen met legenden omtrent de voorouders van de graven, doorweefd met verzinsels nopens Boudewijn den $\mathbf{I}$ en verstrengeld met verkeerde voorstellingen aangaande zijn opvolger, is de vroegste geschiedenis van het Vlaamsch vorstendom een ingewikkeld, moeilijk probleem. Het ligt in onze bedoeling, hier een oplossing van dat vraagstuk te betrachten.

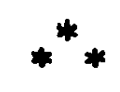

(1) Lambrecht van Sint-OmanRs (M.G.H. SS IX, blz. 309), 1120 ; en Flandria Generosa (midden twaalfde eeuw), ibid., blz. 317.

(2) Naamlooze kronijk van vóor 1194, in DE SMET, Corpus Chronicorum Flandriae, I, blz. 34 (Codex Bruxellensis).

(3) DE SAINT LEGER, De Flandria comitatus primordits, sive de Fabulis quibus primi comitis origines decorantur (Rijsel, 1900), bijlage.

(4) Cf. mijn reeds vermeld artikel over de Forestierslegende. 
In de negende eeuw, was Vlaanderen met heide, bosschen en moerassen bedekt ( $\left.{ }^{(}\right)$. In de vruchtbare valleien en vlakten hadden Franken zich nedergezet, op een substraat van oudere bevolkingen ( ${ }^{2}$ ).

In het noorden van de streek was het landschap totaal verschillend van wat het thans is : omtrent het jaar $400\left({ }^{3}\right)$, was de zee diep in het land gedrongen, vooral in 't Oosten, en had zoo een breede zone van het tegenwoordig vasteland onbewoonbaar gemaakt ( $\left.{ }^{4}\right)$. Dat gebied was daarom niet bestendig overstroomd : in feite kwamen sommige plekken slechts bij hoogtij, ja, bij springvloed onder water te staan, maar natuur-

(1) Mijn vriend, Dr. Tavernier, deed mij opmerken dat de geologie eerder op het bestaan wijst van uitgestrekte heidevelden dan wel van wouden en dat de toenmalige vogelfauna geen typische boschfauna was. Zeer overwegend dus was het land bedekt met heide, kreupelhout en dun gezaaide bosschen. Dit komt overeen met wat Strabo zegt van het land der Menapiërs en Morienen (Strabo, Geographia, uitg. Meineke (Leipzig, 1877), I, blz. 265. Over de moerassen wordt reeds gesproken bij Cesar (De bello gallico, III, 28 ; VI, 5). In het begin der elfde eeuw vertelt Dudo van SaintQuentin hoe Rollo het hem aangeboden Vlaanderen weigert, omdat de streekt te moerassig is (II, c. 28 uitg. Lair., blz. 168). Zie over de toenmalige wouden Blanchard (R.), La Flandre (Rijsel, 1906), blz. 334-36.

(2) Over 't algemeen zijn we de meening toegedaan dat de Frankische overheersching in Vlaanderen geenszins zoo vroegtijdig en zoo massaal was als doorgaans wordt geloofd. Met Holwerds, De Franken in Nederland: in Oudheidkundige MededeELINGen 's RiJks Museum van OUdHeden Te LeIDen, Nieuwe reeks V, 1, blz. 1-46, meenen we dat de Franken het Romeinsch rijk eigenlijk niet hebben veroverd, maar zich eenvoudigweg hebben nedergezet in de door de Romeinen bezette gebieden en de gallo-romeinsche beschaving grootendeels hebben overgenomen tot wanneer in de vie eeuw, hun koningen onafhankelijk van Rome zijn geworden, en ook dat het Vlaamsche land geenszins het kernland der Franken is, doch pas laat door hen werd bezet. Specifiek Frankische archeologica worden in Vlaanderen uiterst zelden aangetroffen, wat bewijst dat de hier gevestigde Franken zelf spoedig opgegaan zijn in de voorafbestaande cultuur.

(3) De overstrooming deed zich voor kort na het opstellen van de Notitia Dignitatum, d. i. naar de laatste opzoekingen, circa 400 ; ik dank deze laatste inlichting aan Dr. P. Lambrechts.

(4) Cf. Briquet (A.), Le littoral du Nord de la France et son évolution morphologique (Parijs, 1930), blz. 4, 6, 10, 16, 18, 204, 279, 368. 
lijk was de landstreek dan toch voor een normale ontginning ongeschikt.

Waar het zeewater vertoefde, legde het klei neder, zoodat de bodem zich allengskens ging verheffen. Deze werking geschiedde natuurlijk zeer traag en geleidelijk, en we gelooven niet dat reeds veel gebied in de negende eeuw op de zee was heroverd. De toenmalige kustlijn stemde dus grootendeels overeen met de zuidergrens van de jongere sedimentaties, door de zee zelf aangebracht, die thans nog de grens van de vroegere overstrooming zeer duidelijk afbakenen ( $\left.{ }^{1}\right)$. Benoorden deze kustlijn treft men in de volgende eeuwen talrijke eilanden aan.

Laten we het eerst hebben over deze vroegere kust: het blijkt uit de geologische kaart dat de zee het diepst in 't Oosten in het land is binnengedrongen. De Vier Ambachten en het Noorden van het huidig Land van Waas zijn nog bedekt met klei, door de zee aangebracht, waaruit blijkt dat deze gebieden vanaf omstreeks 400 onder water kwamen te staan.

Het Noorden van Waas tot aan de duinenreeks MelseleStekene $\left({ }^{2}\right)$, was dus aan zee gelegen en was de grens van het Frankisch colonisatiegebied : dààr immers lagen de domeinen Saleghem $\left({ }^{3}\right)$, Melsele, Baldegem op Sint-Gillis Waas, temidden de uitgestrekte jachtgebieden van den koning (4). Meer in 't Noord-Westen verschijnen later een aantal eilanden : Wulpen, Zuidzand, Koezand, Zaamslag, Testerep. Gansch de Vier-Ambachten bleven trouwens nog lang een samenstel van eilanden en eilandjes ( ${ }^{5}$ ). Maar of deze reeds in de negende eeuw boven water lagen, kan worden betwijfeld : het element - zand dat in hun namen veelal voorkomt, laat ver-

(1) Dit blijkt uit een blik op een geologische kaart.

(2) Dit waren echter geen zeeduinen, doch stuifzand.

(3) Noord-Wes thoek van Vrasene. We danken deze inlichting aan E. H. De Wilde. Bij vergissing staat er in zijn Enkele beschouwingen over het Hof te Voorhout (ANnalen v. D. ounheidkundigen Kring van WaAs, d. 51, $2^{e}$ afl.) (blz. 2), Noord-Oosthoek.

(4) De Karolingers hadden immers een jachtgebied "Forestum " in Waasland, zie verder blz. 552, n. 2.

(5) van Empel (M.) en Pieters (H.), Zeeland door de eeuwen heen, I, Middelburg, z. d. blz. 143.

R. B. Ph. et H. -35 . 
moeden dat het eerst eenvoudige zandbanken waren. Met uitzondering van Testerep, dat reeds in de laatste jaren van de tiende eeuw wordt vermeld, verschijnen ze slechts vrij laat : Wulpen in 1096, Cadzand in denzelfden tijd! Ook de voornaamste centra uit de Vier-Ambachten, Axel en Assenede, verschijnen pas laat: Axel in 991, Assenede in 1108! Totdaar voor het oostelijkste deel van Vlaanderen. In het latere Brugsche Vrije reikte de zee, toen de overstrooming haar hoogste uitbreiding kende, tot vlak bij de plek waar Brugge zou onstaan. Het voorhanden zijn van een betrekkelijk klein getal toponymen op -gem en -zele meer in 't noorden : Dudzeele met Kathem, Aarseele, en Avingezele in de buurt; Michem en Eitegem op Oostkerke; Gaarlem en Gijzeele op Lissewege, Vlissegem ten slotte ( ${ }^{(1)}$; wijst waarschijnlijk op het bestaan van toenmaals bewoonbare eilandjes of op een vroege achteruitgang van de zee ten $N$. en ten N.-O. van Brugge vooral. Het bestaan van terpen of vluchtheuvels te Dudzeele, Zuienkerke en Oostkerke bevestigt ( $\left.{ }^{2}\right)$ deze laatste verklaring; ten Noord Oosten van Brugge reikte de zee tot Oostburg ( $)$.

Eerst in de elfde eeuw worden andere plaatsen, benoorden Brugge, in het eertijds overstroomde gebied gelegen, vermeld.

De IJzermonding was te dien tijde een breede zeeboezem, die in het land binnendrong tot Vleteren en waarin Loo een

(1) Cf. voor die plaatsen : De Langhe (E.), De oorsprong der Vlaamsche Kustolakte (Knokke 1939), blz. 91-94.

(2) Ibid., blz. 61, 91, 97.

(3) Cf.Lib.Trad. - Fragm. uit de $\mathrm{x}^{\circ}$ eeuw - blz. 40 : in loco noncupante Cumbigascura, super fluvio maris ", ibid., blz. 40 : "Cumbescura, in Ostburch ", Diploma van 941, van graaf Arnulf voor Sint-Pieters te Gent : " in.... loco mari proximo vocabulo Cumbescura .. Cumbescura, een vlek te Oostburg, lag dus bij de zee. De naam "Oostburg " schijnt er trouwens wel op te wijzen dat het punt het oostelijk uiteinde was van het vasteland. Wat deze voorstelling staaft, is dat verschillende plaatsen welke thans dichter bij de zee liggen dan Oostburg, uit kerkelijk oogpunt van Oostburg afhingen ; dit geldt voor Groede, IJzendijke, Gaternesse, Vulendike, Ostmundicapelle (vgl. vAN LOKEREN, Chartes et Documents de Saint-Pierre de Gand, $\mathrm{I}, \mathrm{n}^{\mathrm{r}}$ 214, en DuchesNe, Histoire généalogique de la maison de Guines; preuves, blz. 76.) 
eiland was ( $\left.{ }^{1}\right)$. Nog in de tweede helft van de elfde eeuw wordt van deze breede monding gewag gemaakt in de Translatio, Sancti Wandregisili ( $\left.{ }^{2}\right)$. Verder Westwaarts lagen de moeren, een laagland dat nog lang zal overstroomd blijven. Sint Winnoksbergen lag oorspronkelijk aan een zeeboezem $\left(^{3}\right)$ en bleef zoo tot in de twaalfde eeuw ten minste $\left({ }^{4}\right)$. De monding van de Aa schijnt niet zeer aanzienlijk meer te zijn in de elfde eeuw (5), doch verderop lag, tusschen Sangatte en Oye, een breede zeeboezem, Neuna genaamd ( $\left.{ }^{6}\right)$, dit weer in de elfde eeuw. A fortiori dus in de 9e. De kust was ook daar bezaaid met een aantal eilandjes ( ${ }^{7}$ ).

Het kan niet worden uitgemaakt, in welke mate de zee zich in den negende eeuw had teruggetrokken uit het overstroomde gebied. Wanneer echter wordt in 't oog gehouden, dat de grond moest heroverd worden door middel van lastige inpolderingen, waarvan de noodzakelijkheid zich niet opdrong, zal men niet geneigd zijn aan een snelle achteruitgang van de zee te gelooven (8). Deze meening wordt gestaafd door bijkomstige beschouwingen; buiten de enkele Frankische vleknamen, op -gem en -zele, die waarschijnlijk veel ouder zijn dan de negende eeuw, wordt geen enkele plaats uit het overstroomde gebied vóór de elfde eeuw aangetroffen. De plaatsnamen op -kerke en -kapelle, die zoo overvloedig voorkomen in deze streek, duiken pas op in denzelfden tijd ( $\left.{ }^{9}\right)$; tenslotte nog dit: de

(1) Cf. Blanchard, La Flandre, blz. 149.

(2) M.G.H. SS XV, 2, blz. 630 .

(3) Liber Traditionum Sancti Petri (uitg. Fayen, Gent, 1906), $n^{r}$ 117, blz. 107 " juxta castrum Berga, in Gersta supra mare".

(4) Pruvost, Chronique et Cartulaire de Saint Winnoc, I (Brugge, 1875), blz. 87.

(5) Cf. Blanchard, op. cit., blz. 138.

(6) Ibid., blz. 138. Weretha is echter niet Frethun, doch een plek te Sangatte. Cf. A. Briquet, Le littoral du Nord de la France et son evolution morphologique, blz. 284-85. Over de Neuna, cf. ibid., blz. 371 .

(7) Cf. Blanchard, op. cit., blz. 147-149.

(8) Dit is ook de meening van Briquet (op. cit., blz. 369).

(9) Westkerke bij Oudenburg wordt reeds in 877 vermeld (Gúfrard, Cartulaire de Saint-Bertin, blz. 124), doch deze plek ligt buiten het over- 
reeks burchten welke, zooals we verder zullen pogen te bewijzen, door Boudewijn den IIe werden opgericht - vermoedelijk aan de kust - om de Noormannen uit het land verwijderd te houden, - Oostburg, Aardenburg, Brugge, Oudenburg, Gistel, Veurne, Sint-Winnoksbergen en Broekburg - liggen allen op één lijn, die grootendeels overeenstemt met de oude kustlijn, en geenszins met de huidige.

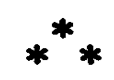

Wie de eilanden van de kust bewoonde, zullen we hier niet trachten uit te maken. In het Oosten is de toponymie bepaald Friesch getint; of, zooals dikwijls werd beweerd (1) Saksers de westelijke eilanden bewoonden, laten we hier in 't midden. Wat echter vast staat, is dat de toenmalige vastelandskust door de Franken was bezet. Het is duidelijk genoeg, dat ze langs de geheele kustlijn door, nederzettingen hebben gesticht, kenbaar aan de plaatselijke agglomeraties van Frankische toponymen. In het Noord-Oostelijk schiereiland van Waas, we hebben er reeds opgewezen, liggen de weinige Frankische nederzettingsnamen dicht bijeen : Melsele, Salegem, Baldegem en, iets bezuiden, langs de Schelde, Belsele en Bazel. Zele ligt geïsoleerd. Dit zijn de domeinen van den pagus Wasiae $\left({ }^{2}\right)$. Aan de westzijde van den "fluvium maris " die in

stroomde gebied. Geen ander plaats op -kerke of -kapelle verschijnt in teksten, naar ons beste weten, v6ór de elfde eeuw.

(1) Iedereen weet dat dit én de klassieke voorstelling was van de romantische school, afdoende weerlegd door VAN Houtre (H.) (Les Kerels de Flandre, Leuven, 1898) én de stelling, door wijlen Des Marez verdedigd in zijn prachtig * Le Problème de la colonisation franque et du régime agraire en Belgique * (Brussel, 1926, 40). Cf. echter VAN Wenveke (H.) - met behulp van aanteekeningen van GaNshof (F. L.) - De Kritiek op Des Marez' voorstelling van de Frankische kolonisatie (NEDERLANdsche HistorieblaDEN, d. I, 1938, blz. 18-26), blz. 22-23.

(2) Ook de villae Hamme, Temsche, Tielrode en Durbecca (d. i. Zombeke bij Waasmunster) die in het land van Waas liggen, worden reeds in de $9^{e}$ eeuw vermeld. 
de tiende eeuw tot Adegem reikte ( $\left.{ }^{1}\right)$, lag een andere groepeering van Frankische hoeven: Maldegem - een koninklijk fiscus - Adegem, Noorthem, Wielinghem (2). Dit was de Frankische nederzetting van den pagus Rodanensis. In het Brugsche eindelijk, meer bepaald in den driehoek Brugge, Oudenburg, Torhout, zijn de Frankische domeinen talrijk: Sijzele, Beernem, Zedelgem, Loppem, Snellegem, Straathem ( $\left.{ }^{3}\right)$ Meshem (4), Bekegem, Roksem, Zerkegem, Eernegem, Ichtegem e. a. Dat alles grootendeels in den pagus Flandrensis. In het Zuid-Westen van de golf van Loo (d. $i$. de breede monding van den IJzer), liggen Wulveringem. Alveringem, Vinkem, Houtem, Leyzele weer bijeen. Dit volstaat om te bewijzen dat de Franken een gebied hebben gecoloniseerd, dat wel met de toenmalige kust overeenstemde, echter geenszins met de huidige.

Vlaanderen was, onder de Karolingers, zooals het overige van het rijk, ingedeeld in gouwen, pagi, in beginsel elk door een graaf bestuurd. (5).

Aan de kust lag tusschen Schelde, Durme-Leede $\left(^{6}\right)$, zee en

(1) Liber Traditionum, $\mathrm{n}^{\mathrm{r}} 41$, blz. 45 (oudste fragment) : "in pago Rodaninse, prope fluvio maris, in loco qui vocatur Addingahem....".

(2) Ibid., blz. 31, $\mathrm{n}^{\mathrm{r}} 20$ : "in pago Rodaninse... in Wialingahem...".

(3) Thans Sint-Andries bij Brugge.

(4) Insgelijks aldaar.

(5) Bij het opstellen van de bladzijden waar over de pagi wordt gehandeld hadden we de verhandeling van onzen vriend Drs. J. Blanquaert, over de Gouwen van Vlaanderen, voor ons liggen. De regels waarin gesproken wordt over de gouw van Artesië, en het volgende, zijn aan deze dissertatie ontleend. Ook een groot deel van het hierbij verwerkte materiaal zijn we hem verschuldigd.

(6) Een woord over de toenmalige hydrographie van Noord-Oostelijk Vlaanderen zal hier niet ongepast zijn.

Tot zoowat de breedte van Deinze loopen twee waterloopen van Zuid naar Noord, het zijn de Schelde en de Leie. Omstreeks Deinze ontspringt de Kale, thans Oude Kale genoemd. Het schijnt thans uitgemaakt te zijn dat de loop van de Oude Kale de primitieve loop van de Leie is, en later een linker uitlooper van deze rivier werd (cf. Stevens (Ch.), Le relief de la Belgique (Mém. de L'Institut géologique de Louvain, t. XII, 1938, blz. 


\section{de waterlinie van Gent naar 't Noorden de pagus van}

264 en sq.). Deze voorstelling wordt merkelijk bevestigd door de pagigrens pagus Mempiscus-pagus Gandensis.

De (Oude) Kale loopt dan ook naar het Noorden, eenigszins evenwijdig met de Leie, doch deze laatste vloeit te Gent in de Schelde, terwijl de (Oude) Kale verder naar het Noorden loopt, om zich te Langerbrugge plots naar het Oosten te wenden en de Bovendurme te vervoegen.

Wat geschiedt er nu stroomafwaarts van Gent? Vele aardrijkskundigen hebben de volgende theorie vooropgezet : De Leie wierp zich oorspronkelijk niet in de Schelde te Gent, doch vloeide zelfstandig voort naar het Noorden en splitste zich te Langerbrugge in twee armen, de eene, welke naar het Oosten toe vloeide, was de bovenloop van de Durme, de tweede, die voort naar het Noorden liep, was de eigenlijke uitmonding van de Leie in zee. Al deze voorstellingen worden op zeer handige wijze voorgestaan door A. Van Werveke in zijn bijdrage. "Etude sur le cours de l'Escaut et de la Lys-Durme au moyen age, a Gand et en aval (BULLETIN DE la Société Royale Belge de Géographie, 1892, d. XVI).

Terwille van de klaarheid zullen we twee problemen uit elkaar houden : $1^{\circ}$ ontstaat de Durme werkelijk uit de Leie te Gent ; $2^{\circ}$ vloeide de Leie vroeger naar den Braakman?

A. YAN Werveke (op. cit., blz. 11-14), heeft volstrekt onweerlegbaar bewezen dat een deel van de wateren der Leie vanuit Gent langs de Schipgracht en den Burggravenstroom naar de Moervaart worden gebracht, en dat deze afleiding van de Leie van oudsher "Durme * wordt genoemd. Dit geldt voor de strook Gent-Langerbrugge. Andere, even overtuigende teksten (ibid.), bewijzen dat ook de strook Langerbrugge-Mendonck deze naam droeg van de $9^{\circ}$ eeuw af ten minste. Verder scheidt de rivier zich in verschillende armen * Leeden * genaamd, o. m. de Noord-Leede en de ZuidLeede. Tenslotte, in het Land van Waas draagt deze waterloop than sog den naam Durme. Het mag dus voor volstrekt bewezen gelden, dat de Durme, in de historische tijden een uitlooper is van de Leie die destijds van Gent af de naam Durme droeg. Ook de (Oude) Kale, welke te Langerbrugge - precies daar waar de Leie-Durme plots van Zuid-Noord, West-Oost gaat vloeien, - in de Leie-Durme loopt, is zooals gezegd, waarschijnlijk een uitlooper van de Leie.

Laten we thans het tweede probleem onderzoeken : liep de Leie vroeger - althans voor een deel - rechtstreeks naar den Braakman? Deze voorstelling schijnt tegengesproken door het bestaan van een heuvelenreeks Zelzate, Stekene, Sint-Gillis-Waas en Vlaamsch Hoofd (cf. A. VAN WERvEKE, op. cit., blz. 15) wat vele aardrijkskundigen, waaronder $A$. van Werveke, toch niet verhinderde ze aan te nemen.

Er zijn echter stevige tekstargumenten noodig om een zoo voor de hand liggende hinderpaal uit den weg te ruimen. $O$. i. heeft $A$. van Werveke 
Waas ( $\left.{ }^{(}\right)$, verder de pagi van Aardenburg, ten Oosten misschien begrensd door den "fluvium maris" die tot Adegem reikte $\left({ }^{2}\right)$, de pagus Flandrensis, die zich ten Westen zeer waarschijnlijk tot aan de breede monding van den IJzer uitstrekte $\left({ }^{3}\right)$, tenslotte de pagus van Boulogne, tusschen Aa en

zulke argumenten niet aangevoerd. Wat hij alleen bewijst is het bestaan in de $16^{\circ}$ eeuw van een vaart van Gent naar Zelzate (op. cit., blz. 15-18). De scheidingslijn van de wateren benoorden Gent ligt thans nog te Ertvelde, waar een lichte niveauverhooging ( 2 meter) wordt waargenomen en van waaruit een riviertje naar Langerbrugge vloeit en een andere naar het Noorden, naar den Braakman. We hechten dus geen geloof aan het bestaan in de hooge middeleeuwen van een rivier die van Gent uit naar den Braakman liep. Wel bestond er daar een feitelijke waterlinie, doch ze was samengesteld r'it twee riviertjes, door den drempel van Ertvelde gescheiden. Aangezien Mendonck in een handschrift van de $x^{*}$ eeuw (Liber Traditionum $\mathrm{n}^{\mathrm{r}}$ 25) op de Durme wordt gesitueerd, vormden de huidige Durme en de Leie-Durme - d.i. de strook Gent-Moervaart reeds één rivier op dat oogenblik, d. $w$. $z$. dat de wateren van de LeieDurme reeds naar het Oosten vloeiden en niet langer een zelfstandige stroom vormden.

(1) Het bestaan van deze gouw wordt wel eens betwist. Ten onrechte, meenen we. Er bestaan immers een zij het klein toch voldoende aantal authentieke vermeldingen van de Waasgouw : $1^{\circ}$ ) het diploma van Karel den Kale (uitg. Prou, Examen d'un diplôme de Charles le Chauve pour Saint-Pierre de Gand, blz. 42-63, bijlage. - B. C. R. H. d. LXXXIV, 1920,) waarvan Grierson de echtheid heeft bewezen (The Translation of the relics of St. Amalberga to St. Peters of Ghent, in Rev. BÉntedictine, 1939, blz. 292-315.) $2^{\circ}$ ) De oorkonde van Arnulf den Groote voor Sint-Pieters, van 941 (uitg. Des Marez, Notice sur un diplome d'Arnulf le Vieux, comte de Filandre (B. C. R. H., 5o reeks, d. VI, 1896, blz. 208-252), bijlage. Cf. SABBe, Étude crilique sur le diplóme d'Arnoul I er comte de Flandre, pour l'abbaye de Saint-Pierre de Gand (ÉTUdes D'HISTOIRE DÉdífes A LA MÉmoIRe de Henri Pirenne, Brussel, 1937), blz. 299-330.

30) Het bevestigingsdiploma door koning Lodewijk van Overzee (uitg. Lauer, Recueil des Actes de Louis IV d'Outremer, Parijs, 1914) $\mathrm{n}^{\mathrm{r}}$ XXXVI. Cf. SABBE, op. cit., blz. 325.

$4^{\circ}$ ) Het bevestigingsdiploma van Lotharius van Frankrijk (uitg. LotHalphen, Recueil des Actes de Lothaire et de Louis V (Parijs, 1908) $\mathrm{n}^{\mathrm{r}}$ 22.) De gouw Waas was een klein en arm gebied, dat vermoedelijk slechts het zuiden van huidig Waasland omvatte.

(2) Cr. hooger, blz. 538, n. 3.

(3) De ligging van den pagus Flandrensis is allerminst duidelijk. Hij lag 
Canche (1). Naar het binnenland toe waren deze kustgouwen begrensd door een reeks andere gouwen : de pagus Mempiscus $\left({ }^{2}\right)$ die zich van Waas tot voorbij Roesselare uitstrekte $(\boldsymbol{})$

aan zee, dat blijkt uit de teksten. Doch waar? Daar de beteekenis van Flandria en waarschijnlijk van pagus Flandrensis zich in de $10^{\mathrm{e}}$ eeuw ging uitbreiden (zie hierna), mag men slechts op de teksten van de 9e eeuw steunen. Ze leeren dat Roksem, Aartrijke, Varsenare, Oudenburg en het ongeidentificeerde illummariscum in Vlaandergouw lagen, alsmede misschien Brugge. Koekelare en Loppem lagen cchter in $\mathbf{M e m}$ piscus, zoodat de pagus Flandrensis slechts een smalle kuststrook van de Kerkebeek tot den IJzer schijnt te zijn. Enkele plaatsen die tusschen IJzer en Aa liggen, worden weliswaar in de $x^{e}$ eeuw "in pago Flandrense " geplaatst; dit geldt voor Bourbourg, (Lib. Tradit., blz. 94) voor Frilingim (d. i. Ferlingehem bij Noordpeene (ibid., blz. 80), Uxem (ibid., blz. 89), doch hierop kan niet worden gesteund, omdat deze vermeldingen alle uit de laatste jaren van de $x^{e}$ eeuw dagteekenen, $d$. $i$. een tijdperk, waar het begrip "pagus" in verval was geraakt en waarin tevens "Flandria * niet langer meer het gebied tusschen IJzer en pagus Rodanensis aanduidde, doch het Vlaamsch Vorstendom. Dit blijkt namelijk reeds bij Folcuinus : wanneer deze zegt (uitg. Guerard, blz. 140) dat Boudewijn de $I I^{e}$ aan zijn oudsten zoon "Flandria" liet, en aan den jongeren Adalolf, "Bononia " spreekt het van zelf, dat met de eerste term het vorstendom wordt bedoeld. $O$. i. mag men dus niet steunen op de vermelding van Bourbourg, Ferlingehem en Uxem in de gouw Vlaanderen, om deze gouw tot over den IJzer uit te breiden. Het bestaan van een zoo aanzienlijke hinderpaal als de golf van Loo maakt het, naar we meenen, heelemaal onmogelijk, dat beide oevers van den zeeboezem tot eenzelfde gouw zouden hebben behoord. Daarbij dient nog in't oog te worden gehouden dat daar ook den grens tusschen de bisdommen Doornik en Tewaan liep, die wel op een administratieve grens zal berusten.

(1) De gouw Boulogne wordt herhaaldelijk geciteerd in het cartularium van Sint-Bertijn, in teksten welke over de gansche negende eeuw gaan.

(2) Zomergem is het meest oostelijk gelegen punt van deze gouw, dat mij bekend is (Lot-Halphen, Actes de Lothaire, $\mathbf{n}^{\mathrm{r}}$ 22).

(3) Het meest westelijke punt dat mij bekend is, zijnde Roesselare zelf (Duvivien, Recherches sur le Hainaut ancien (Bergen, 1865), I, blz. 294, a 822 : "in pago qui dicitur Mempiscus, in loco nuncupante Roslar ". Het is wel interessant, dat weze terloops gezegd, aan te stippen, dat de oppervlakte van de fiscus Roesselare in 822 nagenoeg dezelfde is als deze van de huidige stad. Immers, deze laatste beslaat $2313 \mathrm{Ha}$. Welnu uit het diploma van Lodewijk den Vrome blijkt dat het domein 118 mansi bedroeg. Een mansus zijnde gelijk aan circa 16 hectaren (cfr. Grierson, The identity of the unnamed fiscs in the "Brevium exempla ad describendas res ecclesia- 
zoodat zijn oostergrens vermoedelijk samenviel met de scheidingslijn tusschen de bisdommen Terwaan en Doornik (1). Bewesten deze lijn, tot aan den IJzer en de Vleterbeek ( ${ }^{2}$, misschien op den anderen oever van den IJzer nog $\left({ }^{3}\right)$, lag de pagus Iseretius $\left({ }^{4}\right)$. Nog verder in het Zuid-Oosten, de gouw Ter-

sticas et fiscales - - R. B. Ph. H., d. XVIII, 1939, blz. 437-462 -, blz. 443), bedroeg de oppervlakte van de fiscus Roesselare dus ongeveer 2122 ha. Weinige geidentificeerde plaatsen worden in teksten die tot voor het jaar 1000 opklimmen, "in pago Mempisco " gelocaliseerd. Slechts met Roesselare, Wakken, Zomergem, Aalter, Hamme, op de Marsbeek te Sint-Michiels bij Brugge, en Broekem, op de Kale (Gemeente Mariakerke bij Gent) is dit het geval. Deze laatste identificatie is van J. Blancquaert.

(1) Deze grens liep van de Leie omtrent Waasten naar de Zarrebeek omtrent Zarren en verder langs Zarrebeek en IJzer. Cf. DE SchePPER, De grenzen van het oud Bisdom Doornik (Collationes Brugenses 1921, blz. 130-138).

(2) Dit blijkt uit de naam zelve van de gouw "Iseretius * of IJzergouw.

(3) Het is feitelijk niet uit te maken tot welken pagus domeinen die op den noord-westelijken oever van de golf van Loo (IJzermonding) lagen, behoorden. Geen enkele van hen wordt immers vermeld.

(4) Het bestaan van deze gouw wordt wel eens betwist, omdat ze slechts éénmaal vermeld wordt. Zoo 'n argumentatie begrijpen we niet. De geschiedenis is toch geen numerieke wetenschap? Het volstaat o. i. dat een gouw énmaal vermeld staat in een authentiek, onaangevochten stuk, opdat het bestaan van den pagus zou vast staan. Dit is het geval met Iseretius : nog nooit werd de echtheid van de oorkonde van het jaar 811 waarin "Fletrinio, in pago Iseretio" (Guerard, Cartulaire de SaintBertin, blz. 68), d. i. Vleteren (thans Oost en West-Vleteren), staat, betwist. Daarbij komt dat geen enkele vermelding van plaatsen "in pago Mempisco * in bronnen wordt aangetroffen, beoosten Koesselare, in het vermoedelijke gebied van Iseretius, vóór de periode die aan de inpalming van Iseretius door Mempiscus (midden negende eeuw) voorafgaat. De Vleterbeek scheidde Iseretius van Ternois (Guerard, ibid., blz. 117). Men moet dus gelooven aan het bestaan van een IJzergouw, die zich vermoedelijk tusschen IJzer (of zee ?) Vleterbeek en grens tusschen de bisdomm en Terwaan en Doornik uitstrekte.

Maar tusschen 811 en 846 heeft de pagus Mempiscus de Iseretius opgeslorpt. Dit blijkt hier uit : in 846 (Halkin-Roland, Recueil des chartes de l'abbaye de Stavelot Malmédy, I, Brussel, 1909, blz. 78) worden goederen : "in pago Mempisco... super fluvium Ysere" vermeld. Ergo reikt de Mempiscusgouw dan tot aan den IJzer, heeft Iseretius dus (tijdelijk?) opgeslorpt. 
waan. Pagus Mempiscus, Iseretius en het oostelijk deel van Terwanensis vormde de streek "Mempiscus" ( $\left.{ }^{1}\right)$.

Laten we naar Oostelijk Vlaanderen teruggaan : Benoorden de Schelde, stroomafwaarts van Gent, en de Leie, stroomopwaarts van deze stad, bezuiden de Oude Kale (), en haar voortzetting de Leede-Durme, lag de pagus van Gent $\left(^{(3)}\right.$.

(1) Mempiscus is niet hetzelfde als pagus Mempiscus : het is een uitgebreid gebied dat vanzelfsprekend pagus Mempiscus omvat, echter ook het gebied ten Noord-Westen van de IJzermonding (Esquelbecq, * in Mempisco, anno 853, Gutrard, op. cit.. blz. 95) tevens een deel ten minste van Ternois, (Krombeke, in pago Tarvanense, intra Mempiscum, GuERARD, op. cit., blz. 48 ; Ledringen.. idem, (ibid., blz. 49) ; "Mekerias ", idem, (ibid. blz. 115) ; Strazeele, idem (ibid., blz. 116) en zich zelfs tot bewesten de Aa uitbreidt (Elceka in Mempisco), R. H. F. III, blz. $625=$ Ausque (Nordausque en Sudausque.)

(2) Het Liber Traditionum, fragment van de $x^{\text {eeuw }}$ (blz. 41) vermeldt - in pago Menpisco sive Gandinse... Brochingahem, super fluvio Dormia *. Taalkundig kan Brochingahem slechts Broekem geven, dat we trouwens in het Liber Tradit. aantreffen (blz. 94 "Bruchem ", blz. 103, "Bruchim "). Een Broekem ligt te Mariakerke bij Gent, op de Kale, en het schijnt onbetwistbaar dat genoemde rivier de pagi van Gent en van Mempiscus scheidt. Brochingehem is dan zeker Broekem, doch hoe het super fluvio Dormia * te verklaren? We zegden reeds (zie blz. $542, n$.) dat de rivier, welke van Gent naar het Noorden vloeit, Durme wordt genoemd, en deze rivier loopt inderdaad door Mariakerke, niet ver van Broekem. Mag men dan niet vermoeden dat de plek Broekem vroeger uitgestrekter was dan nu, en in 't Oosten tot aan de "Durme * reikte?

(3) Het bestaan van den pagus van Gent in de viri eeuw blijkt uit verhalende en diplomatische bronnen. De Vita Amandi (eerste vierde der eeuw) gewaagt van "pagum quemdam praeter fluenta Scaldi fluvii, cui vocabulum Gandao indidit antiquitas" (M. G. H., SS. RR. Mer. V, blz. 436), terwijl de gelijktijdige Vita Eligii (ibid. blz. 695) het "municipium * Gent, naast de "civitates " Saint-Quentin, Doornik en Noyon samen met de municipia Kortrijk en Vlaanderen vermeldt. Uit de gelijkstelling met Vlaandergouw blijkt dat municipium hier gouw beduidt. Vroeger nog, in een oorkonde van 707, wordt Afsnee in pago Gandensi gesitueerd (Liber Traditionum, blz. 25-24). De geidentificeerde plaatsen die vóor het jaar 1000 - daarna verliest het begrip gouw alle beteekenis - " in pago Gandense worden vermeld zijn Ekkergem te Gent, Ham te Gent, Goedingen te Evergem, Marke bij Ekkergem, Meerendree, Vinderhoute, Vosselaar, Afsnee, Mendonck, Zingempolder, Goed te Bergen, Goed te Sloten en Ledergem, alle vier op het gebied van Oostakker, Papegem, Berchelen bij 
Aan de overzijde van de Kale lag den reeds vermelden $p a-$ gus Mempiscus.

Tusschen Schelde en Leie lagen in het Noorden, tot voorbij Lauwe, de pagus Cortracensis, in het Zuiden, de pagus Tornacensis $\left.{ }^{1}\right)$. Ten tijde van Lodewijk den Vrome werd de eerste gouw tijdelijk met de tweede vereenigd $\left(^{2}\right)$.

Wetteren ( ?), Hemthorp te Heusden en Heusden zelf. Worden verder vernoemd als ten deele in de Gentergouw, ten deele in de Kortrijkergouw gelegen : Latem, Brakel en Heibergen te Latem, een aantal andere plaatsen langs deze rivier gelegen en Lenslotle Machelen bij Deinze. Vele van deze gegevens dank ik aan J. Blancquaert.

(1) Uit den hooger n. 3 vermelden passus uit de Vita Eligii blijkt dat de Kortrijkergouw in het begin der viI ${ }^{\mathrm{e}}$ eeuw reeds bestond. Deze pagus wordt ook bij name vermeld in de rijksverordening van Servais. Het ware trouwens ondenkbaar dat de civitas Kortrijk (cf. Prou, Les monnaies carolingiennes, $\mathrm{n}^{x}$ 179) niet het hoofd ware van een gouw.

De bekende plaatsen, in betrouwbare teksten vermeld en in de Kortrijkergouw gesitueerd, zijn : Boenlare te Petegem-Deinze, Koolegem te Deurle, Zingem, Ouwegem bij Kruishoutem, Kruishoutem zelf, Beveren aan Leie, Beveren bij Oudenaarde, Andelgem, Tiegem, Desselgem, Potegem op Waaregem, Steenbeek te Desselgem, Waregem, Kaster. Avelgem in 't Oosten, Lauwe in 't Westen, schijnen voor een deel in het Doorniksche voor een deel in 't Kortrijksche te zijn gelegen. Daar liep dus de grens tusschen beide gouwen.

(2) Dit blijkt hier uit : in 814 en in de volgende jaren strekt de Tornacensis zich onbetwistbaar uit tot aan Gent, vermits de Sint-Pieters-abdij uitdrukkelijk " in pago Turnacense " wordt gesitueerd (Lib. Trad., blz. 9), ook Welden (Wildio, ibid., blz. 23), Bekkelinge te Sinte-Maria-Leerne (ibid.). Anderzijds echter blijkt de Kortrijkergouw reeds in het eerste vierde der vin eeuw te bestaan (Vila Eligii, M. G. H., SS. RR. Merov IV, blz. 695 : " municipiorum... Flandrensi, Gandensi etiam et Corturiacensi ". Uit het parallel met " Flandrensis * blijkt voldoende, dat municipium hier - pagus " beduidt.

Deze schijnbare tegenstrijdigheid der bronnen wordt opgehelderd, wanneer men opmerkt dat al de vermeldingen van plaatsen, die aardrijkskundig in de Kortrijkergouw dienen te liggen, en toch * in pago Tornacense * worden gesitueerd, in oorkonden staan, tijdens de regeering van Lodewijk den Vrome gegeven. Zoo is alles opgehelderd : de Kortrijkergouw werd, voor een ons onbekende reden, door dezen keizer bij de Doornikergouw gevoegd. Uit de verordening van Servais (853) blijkt dat deze regeling door zijn opvolger werd te niet gedaan.

Tegen onze meening zou kunnen gelden dat de schenking van *Thiabo- 
De gouw van Artesië lag beoosten deze van Ternois. De grens tusschen de twee graafschappen zal vermoedelijk wel met deze van de twee gelijknamige bisdommen hebben overeengestemd, d. w. z. de loop van de Clémance hebben gevolgd. De Sensée schijnt de afbakening tusschen de pagi van Atrecht en Kamerijk te hebben uitgemaakt. De zuid-oostelijke hoek van het latere vorstendom Vlaanderen omvatte een reeks pagi van zeer uiteenloopend belang : Oosterbant, Caribant, Melantois, Pevele, Escrebieu en pagus Leticus (1).

dingahem, super fluvio Scalde, in pago Tornacense" (Liber Traditionum, blz. 43) ten tijde van Karel den Kale werd gedaan. Thiabodingehem zijnde Tiegem, dat alleszins in de gouw Kortrijk diende te liggen.

Hiertegen zou reeds mogen aangevoerd, dat het wel mogelijk is, dat de vereeniging van de twee pagi nog een tijdlang onder Karel den Kale bleef voortbestaan en dat bedoelde, niet nader gedagteekende schenking in deze periode valt. Maar dat in ' $t$ midden gelaten, geven we geenszins toe dat Thiabodingahem, zooals Adzo (Biekorf, d. XIX, 1908, blz. 129-131) beweert Tiegem zou zijn. Eerst, omdat Tiegem niet op de Schelde ligt, ten tweede, omdat Thiabodingahem in de elfde eeuw (Lib. Trad., blz. 42) nog in de Doornikergouw wordt geplaatst, wat niet het geval is met de andere domeinen die tijdens Lodewijk den Vrome's regeering, alhoewel ze in den pagus Cortracensis thuis hooren, als gelegen in den pagus Tornacensis worden vermeld ; tenslotte nog, omdat een autoriteit op het gebied der toponymie als J. Mansion de identificatie van Adzo impliciet verwerpt door voor Thiabodingahem te bekennen * ligging onzeker * (Oud Gentsche Naamkunde, blz. 30.)

(1) Het bestaan van de gouwen Ternois en Artois de geheele $\mathrm{Ix}^{\circ}$ eeuw door hoeft wel niet te worden bewezen. Overtalrijk zijn hiervan de vermeldingen. Oosterbant wordt in de $\mathrm{Ix}^{\circ}$ eeuw vermeld in de Miracula $S$. Quintini (M. G. H., SS. XV, I, blz. 269), in een diploma van Karel den Kale van 847 (Duvivier, Hainaut ancien, $I$, blz. 297), in een ander van denzelfden koning van 877 (R. H. F., VIII, blz. 666) en nog in verscheidene andere teksten. Melantois wordt vermeld in een rijksverordening van Lodewijk den Vrome (anno 831, Boretius, Capitularia, II, blz. 24) in verscheidene diplomas van 864 (Serrure, Saint-Bavon, $n^{r}$ 4), 874 (De Coussemaeker, Cartulaire de Cysoing, $\mathrm{n}^{\mathrm{r}}$ 5) en 877 (R. H. F. VIII, blz. 606).

Twee diplomas van Karel den Kale, het eene van 847 (Hainaut Ancien, blz. 297) het andere van 877 (R. H. F. VIII, blz. 606), bewijzen het bestaan van de gouw van Pevele. De gouw Leticus tenslotte wordt vermeld in het reeds aangehaald diploma van 877 .

Wat de gouwen Caribant en Escrebieu betreft, kan men haar bestaan 
Totdaar voor de bestuurlijke inrichting van het land. $\mathrm{Nu}$ een woord over het grondbezit.

De ontgonnen gebieden van Vlaanderen waren meestal ingedeeld in groote uitbatingseenheden "villae ", of domeinen die aan een gering aantal grondbezitters toebehoorden (1). Kleine vrije boeren schijnen nogal weinig talrijk te zijn geweest ( ${ }^{2}$ ).

Benevens de leeke heeren, moet onder de grondeigenaars worden vermeld, de Kerk en meer bepaald de abdijen en kapittels, zoowel deze uit, als deze buiten Vlaanderen; doch veel meer nog dan de Kerk, bezat de koning hier domeinen.

Weinebrugge $\left({ }^{3}\right)$, Snellegem $\left({ }^{4}\right)$, Maldegem $\left({ }^{5}\right)$, waren fisci. Ook, verder naar het binnenland toe, Roesselare met de afhankelijkheden Hardooie, Koekelare, Hooglede, Rijkegem bij Tielt, Koolskamp, Wingene, Beernem, Boonaarde bij Kortrijk ( $\left.{ }^{6}\right)$. Omtrent Gent lag de fiscus Marke bij Ekkergem mit talrijke afhankelijkheden waaronder Evergem en Goedinge bij Evergem( (7). Een ander fiscus was ook de villa Aaigem (Sint-

in de $\mathrm{Ix}^{\circ}$ eeuw niet bewijzen, daar de vroegste vermeldingen van dez in de tweede helft der $x^{\circ}$ eeuw vallen.

(1) Cf. Pirenne, Liberté et propriété en Flandre du VII' au XI' siècle (Bull. de l'Acad. de Belgique, Cl. Lettres, 1911, blz. 496-523), en van WeRveKe (H.), Grands propriétaires en Flandre au VII' et VIII' siècle (R. B. P. H., 1923, blz. 321-327), en een sprekende tekst in de Miracula S. Bertini ( \pm 890$)$ M. G. H. SS. XV, blz. 513.

(2) In het Liber Traditionum van de $x^{\circ}$ eeuw hebben we slechts twee vermeldingen aangetroffen van allodia: te Zingem (blz. 43) en te Machelen bij Deinze (blz. 29).

(3) Te Sint-Michiels bij Brugge ; als fiscus vermeld in Liber Traditionum, blz. 64,75 .

(4) Ibid., blz. 51, 64, 70, 73.

(5) Ibid., blz. 74.

(6) Door Lodewijk den Vrome aan Saint-Amand op de Schelde gaschonken (R. H. F., VI, blz. 530).

Dat stuk vermeldt slechts "Roslar, cum appendiciis suis..." De inhoud van de gift wordt echter nader bepaald in 847 in Mempiscum Rollare, Hardoga, Cokenllare, Ledda, Ricoluvingaheim, Coloscampum, Wenghinas et Berneham et Bonart *. Deze plaatsen werden op voortreffelijke wijze geidentificeerd door vaN CAPPEL (Pagus Mempiscus, in ANNALES dE LA Société d'Émulation de Bruges, d. LX, 1910, blz. 105-134.)

(7) Serrure, Cartulaire de Saint-Bavon, $\mathrm{n}^{\mathrm{T}} 4$, anno 864 ' in pago Gan- 
Pieters-Aaigem) (1). Gansch het domein van Sint-Pieters te Gent schijnt trouwens een koninklijke schenking te zijn (2). Stroomafwaarts van Gent, op de Schelde, Temsche ( ${ }^{3}$ ). Stroomopwaarts van Gent, langs de Leie, Petegem bij Deinze ( $\left.{ }^{4}\right)$. Verder in het zuiden waren de fisci nog talrijker : Doornik ( ${ }^{5}$ ) Cysoing, Vitry ( $\left.{ }^{6}\right)$, Somain ( $\left.{ }^{7}\right)$, Hollain ( $\left.{ }^{8}\right)$, Harnes met talrijke afhankelijkheden : Aunay, Loison, Vendin-le-Viél, Neuville bij Wez-Welvain, Hennin, Lens, e. a. ( $\left.{ }^{9}\right)$, Roncin-en-Melantois

dense, in villa, que dicitur Marca ". Diploma van Lotharius, 966 (Lot-HAxPHEN, Recueil des Actes de Lothaire et de Louis V, $\mathrm{n}^{\approx}$ 26), "Fiscus Marca cum omnibus appendiciis, id est in Maglina mansus $I$ et villa Gundinglehem, Evergehem cum ecclesia, Dotnest cum silva in qua possunt saginari porci mille, dominicalis curtis Fronestalla (Vronestalle bij Wondelgem, cf. Mansion, Oud-Gentsche Naamkunde, blz. 105) ad quam haec praedicti fisci respiciunt ". Brief van Othelbold (SERrure, op. cit., $\mathrm{n}^{\mathrm{r}}$ 12) : * inter Marka et Ekkeringahem *. Dit laatste is de wijk te Gent, Ekkergem genaamd en bewijst dat Marka daar in de buurt lag.

(1) Aan Sint-Pieters te Gent geschonken door koning Dagobert (Lib. Tradit., $\mathrm{n}^{\mathrm{r}}$ 4).

(2) Liber Trad., oudste fragm. blz. 17, $\mathrm{n}^{\mathrm{r}} 4:$, Ratio de villa Hatingem (Aaigem) et de alia terra que in circuitu adjecet monasterio quam ex largitione regis Dagobertis sanctus Amandus memorato loco dedit".

(3) Cf. Grierson, The translation of the relics of St Amalberga (REvuE Bénédictine, 1939,)

(4) Dat Petegem een fiscus was, berust op twee feiten : koning Karel de Kale heeft daar verbleven, vermits een oorkonde voor Sint-Baafs daar werd gegeven (SERrure, op. cit., $\mathrm{n}^{\mathrm{r}}$ 4); de plek bezit, zooals de meeste fisci, een Martinuskerk.

(5) Cf. Pirenne, le fisc royal de Tournai (Mélanges F. Lot, blz. 641-8).

(6) Cf. Grienson, The unnamed fiscs in the "Brevium exempla ad describendas res ecclesiasticas et fiscales * (R. B. P. H., 1939, blz. 437-459).

(7) De Coussemaeker (I), Cartulaire de l'abbaye de Cysoing (Rijsel, 1890), $\mathrm{n}^{\mathrm{r}}$ 3: "Fiscum nomine Summinium in pago Hostrevant situm ". Het geldt hier Somain en Ostrevant, Dep. Nord, arr. Douai, canton Marchiennes.

(8) Lib. Trad., blz. 85, $\mathrm{n}^{\mathrm{r}} 86$ "regium fiscum Holinium dictum situm in pago Tornacensi cum aecclesia in honore Sancti Martini, et omnibus ad se pertinentibus, id est Ramelgeis (Ramegnies, ten N.-O. van Saint-Amand)... Lesdennium (Lesdain) Nova quoque villa (Neuville, voorstad van Doornik - identificatie van J. Blancquaert) - et quicquid pars fisci sperare videtur... ", anno 974.

(9) Lot-Halphen, Actes de Lothaire, n XL, p. 96 : "de fisco Harnas... 
met de afhankelijkheid Templeuve ( $\left.{ }^{(}\right)$, Haisnes en de afhan-

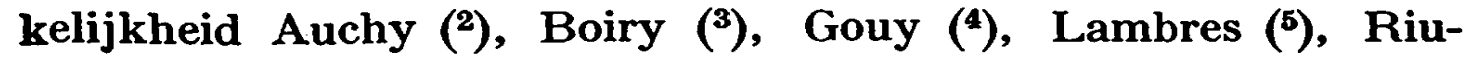
lay (\%), Wavrechin ( $\left.{ }^{(}\right)$, Anzin in Oosterbant ( $\left.{ }^{8}\right)$, Beuvry en Pevele (9), Merck bij Calais (10), Valençijn (11).

Dit is verre van alles! Natuurlijk zijn we niet volledig ingelicht over de koninklijke bezittingen in Vlaanderen, maar dit terzijde gelaten, moeten we er nog op wijzen dat de koning eigenaar was van alle woeste, braakliggende of nieuwe gronden, en o. m. van de wouden, waaronder het Scheldehout tusschen Schelde en Vijve (12), de "Forestum Methela" tusschen Vijve

sito in pago Scarbiu, cum omnibus ad se pertinentibus, id est Aldnais (Annay, Pas de Calais, arr. Bethune, canton Lens-Est), similiter Loyson (Loisonsous-Lens, id.). Wendinio (Vendin-le-Viel, id.) cum terra ad supradictum fiscum respiciente et quidquid pars fisci sperare videtur in circumjacentibus villulis, scilicet in Novavilla, in Heninio (Henin-Liétard? Pas-de-Calais, arr. Arras, canton Croisilles) in Genella, in Lens (Pas de Calais, arr. Bethune)...

(1) Karel de Kale schenkt in 877 aan de abdij Marchiennes "... in pago Medenentinsi, villam Rumcinium, cum appendice ville Templovio * (R. H. F. VIII, blz. 667).

(2) Ibid., "in pago Letico, villam Haignas cum appendice villa Nantgiaco.

(3) Ibid., "in pago Atrebatensi, villam Bariacum ".

(4) Ibid., * in pago Ostrebanno, villam Gaugiacum, in Lambras mansum unum... de villa Rullagio ".

(5) Lambras wordt uitdrukkelijk als "regius fiscus * vermeld in de Gesta episcoporum Cameracensium, II, c. 16. Zie ook voorgaande noot.

(6) Cf. hierboven, noot 4.

(7) In 877 schenkt Karel de Kale aan de abdij Hasnon : in pago Ostrebanto... villam Azinium... super fluvium Scaldim; in prefato pago... villam Wavercinium; in comitatu Tardanensi, villum Auciacum situm super fluvium Wellula *. (R. H. F. VIII p. 662-663).

(8) Zie vorige noot.

(9) R. H. F., VIII, blz. 667 : "in pago Pabulensi, villam Brebrogium *. (10) Folcuinus, uitg. Gú́rard, blz. 142 : "Fiscum Merki ".

(11) Vita S. Salvii. R. H. F., III, blz. 646-647.

(12) Dat het tot aan de Schelde reikte blijkt uit den naam; voor de andere begrenzing, cf. Vercauteren, Etude critique sur un diplóme original d'Henri I $I^{\mathrm{er}}$, roi de France, B. C. R. H., b. CI, blz. 187-213; : communia in Scheldeholt juxta fluviolum Fista et Fiva (De Fista is de Vichte, de Fiva de Vijve). Het "Scadeholt " wordt onder de koninklijke wouden vermeld in het capitularium van Kiersy van 877 (Boretrus-Krause, Capitularia regum Francorum, II, blz. 361). 
en Leie (1), het "Forestum Wasdae " in Waasland (2).

Wijzen we er echter op dat vele van de hier opgesomde bezittingen van den koning hem in de negende eeuw niet meer toebehooren. Door den band kent men immers haar bestaan slechts door de acte van afstand. Maar we beschikken toch over voldoende gegevens om te besluiten dat de Karolingers hier te lande een buitengewoon uitgebreid domein bezaten.

\section{De Rijksverordening van Servais (3).}

$\mathrm{Na}$ te hebben vastgesteld, welk aspect het land bood toen het vorstendom Vlaanderen ontstond, en aan wie de grond dnar in toebehoorde, dient het te worden uitgemaakt, wie het gebied waarop Vlaanderen zou oprijzen, beheerde. Een

(1) Lib. Trad., blz. 66, 69 : *Forestum Methela *; ibid.; blz. 116 : "Forestum Methela, que conjacet villae Thraslingim et Beverne ". Dit geldt Desselgem en Beveren aan Leie. De term * forestum * wijst op een koninklijk jacht geloied.

(2) Een diploma van koning Lotharius van Frankrijk (uitg. HALPHEN-Lot, Recueil des Actes de Lothaire et de Louis V (Parijs, 1908), $\mathrm{n}^{\mathrm{r}} \mathrm{XXXII}$, en OppermanN, Funtes Egmundenses, Urk. 3) vermeldt de "Forestum Wasda in eodem comitatu . Daar dit "forestum " door den Franschen koning aan den graaf van West-Friesland wordt geschonken, ligt het heel zeker binnen West-Francië, echter nabij de Scheldegrens. In dat gebied ligt er slechts een "comitatus, of gouw, die "Wasda " kan worden genoemd, $\mathrm{nml}$. de pagus Wasie zelf. We mogen dus gerust in het "Forestum Wasda " het koninklijk jachtgebied in het Land van Waas zien. OPpermans, op. cit., inleiding blz. 104-10t, meent dat * forestum * hier werd ingebracht door een vervalscher, in stedo van andere bezittingen. Het kan ook, meent hij, een eenvoudige schrijffout zijn voor * fundus *.

Vat er van zij, in de twaalfde eeuw daagt deze foresta weer op : een oork:onde van Diederik van den Elzas spreekt van het silvam que dicitur Conigesfurst " (uitg. DE SMEt, Corpus Chronicorum Flandriae, I, blz. 706) en in 1159 hoort men van de "silva que conincs forest dicitur (P. J. GoETschalckx, Oorkondenboek der Witheerenabdij van Sint-Michiels (EekerenDonk, z. d., blz. 190).

(3) Bij het behandele van dit punt heb ik in ruime mate gebruik gemaakt van aanteekeningen mij door mijn vriend $\mathrm{Ph}$. Grierson ter hand gesteld. De hier gegeven oplossing van de indeeling van missaticum III is daar grootendeels aan ontleend. Dit probleem werd reeds meesterlijk - den tijd in aanmerking genomen - behandeld door VANDER KINDERE 
beroemde tekst, het capitularium van Servais, in 853 door Karel den Kale afgekondigd, verstrekt ons daaromtrent eenige gegevens ( ${ }^{1}$ ).

In deze verordening stelt Koning Karel afgevaardigden aan, met opdracht den vrede in het koninkrijk te doen heerschen. Met het oog daarop wordt het rijk in twaalf gebieden of " missatica " ingedeeld; in elk "missaticum " worden eenige heeren, geestelijken en leeken, met het handhaven van de orde gelast. Ze worden doorgaans gekozen onder de vooraanstaanden van het betrokken missaticum zelf. De gouwen van Vlaanderen worden in het capitularium van Servais ondergebracht in missatica III en $I V$.

Eerst moet worden uitgemaakt welke pagi van Vlaanderen bij missaticum III en welke bij missaticum $I V$ behooren.

De bisschop van Doornik is missus voor missaticum III en deze van Terwaan voor missaticum IV. Het mag dus gereedelijk worden aanvaard dat de gouwen van het bisdom Doornik onder het eerste, deze van het bisdom Terwaan onder het laatste zendelingsgebied thuis hooren. Daarmee is echter niet alles in ' $t$ klare getrokken! Een aantal gouwen uit Vlaanderen zijn immers in géén van beide bisdommen gelegen, daar ze deel uitmaken van het bisdom Atrecht.

Dit laatste bisdom was verbonden met dat van Kamerijk dat in Lotharingen, dus buiten het rijk van Karel den Kale, lag. Dit verklaart dat de bisschop van Atrecht-Kamerijk, geen onderdaan zijnde van Koning Karel, in deze verordening niet als missus wordt genoemd. Wat gebeurde er echter met de pagi van het bisdom Atrecht? De tekst van de verordening duidt het aan : de pagus van Artois immers, één der vier gou-

(Le Capitulaire de Servais et les origines du Comté de Flandre, B. C. R. H. $5^{\text {e }}$ reeks, d. 7).

(1) Bohetius-Krause, Capitularia Regum Francorum, II, blz. 275 : "III. Immo episcopus, Adalardus abba, Waltcaudus, Odelricus, missi in Noviomiso, Vermendiso, Adertiso, Curtriciso, Flandra, comitatibus Engilramni et in comitatibus Waltcaudi.

IV. Folcoinus episcopus, Adalgarius, Engiscalcus et Berengarius, missi in comitatu Berengarii, Engischalchi, Gerardi et in comitatibus Reginarii ". R. B. Ph. et H. -36 . 
wen van het bisdom, wordt opgesomd onder missaticum III. Het blijkt dus dat de pagi van het bisdom Atrecht werden ondergebracht in de naburige missatica, d. i. III en IV. Thans blijft nog uit te maken in welk van beide elke gouw werd ingedeeld.

Voor Artois is alle twijfel uitgesloten, vermits de verordening het zelf noemt bij missaticum III. Dan kan een ander gouw van het bisdom Atrecht, Ostrevant, dat tusschen de Lotharingische grens en Artois gelegen is, ook slechts bij het missaticum van Doornik behooren. Doch waarheen met de twee overige pagi : Leticus en Escrebieu, die naast Ternois, een gouw van missaticum IV, liggen?

Ze kunnen slechts tot missaticum IV, - dat van Terwaan - behooren : uit den tekst van de verordening blijkt immers dat missaticum IV minstens vijf pagi moet omvatten (1). Welnu er zijn er in 853 slechts drie in het bisdom Terwaan ( ${ }^{2}$ ). Indien echter de twee overblijvende pagi van het bisdom Atrecht bij dit missaticum worden gerekend, bereikt men het gewenschte getal.

Missaticum III omvatte dus : pagus Flandrensis, Aardenburg, Waas, Gent, Kortrijk, Doornijk, Artesië, Ostrevant, Pevele, Melantois, Caribant, Vermandois en Noyonnais.

Missaticum IV omvatte: Mempiscus-Iseretius, Boulogne, Ternois, Escrebieu, Leticus.

Thans is de vraag, wie elk van deze gouwen beheerde.

Drie van de graven die gouwen bezitten in missaticum III, worden bij name genoemd : Odelricus, Waltcaud en Ingelram. Uit den tekst van de verordening blijkt dat de pagi van het missus-gebied in drie groepen dienen te worden ingedeeld: deze van Ingelram (... comitatibus Ingelramni), deze van

(1) Zie vorige noot.

(2) Bononiensis, Teriwanensis en Iseretius of Mempiscus. Mempiscus ligt in werkelijkheid in het bisdom Doornik, dus in het andere missaticum, doch in 846 (zie hooger, blz. 545 n. 4) blijken Mempiscus en Iseretius énzelfde graafschap uit te maken, beheerd door Berengarius. Aangezien er 5 gouwen moeten liggen in missaticum IV moet of Iseretius, of MempiscusIseretius, daaronder zijn begrepen. 
Waltcaud (... comitatibus Waltcaudi) en de overige, die bij name worden genoemd (Noviomiso, Vermendiso, Adertiso, Curtrisco, Flandra). Geleerden hebben, bladzijden lang, getwist over de vraag of deze laatste graafschappen al dan niet de graafschappen van Ingelram waren, wat inderdaad uit den tekst zou kunnen besloten worden ${ }^{(1)}$. Er bestond nochtans een zeer eenvoudig middel om uit de verlegenheid te geraken; onderzoeken of de graaf van een der opgesomde gouwen, soms niet bij name bekend was. Indien immers 't zij voor Vermandois, of voor Artesië, of voor Kortrijk of Vlaanderen of Noyonnais, een graaf in 853 wordt vermeld, die Ingelram niet is, volgt daaruit dat "comitatibus Ingelramni" geen bijbepaling is van Noviomiso, Vermendiso, etc. Welnu zoo'n graaf bestaat, nml. Odelricus, dezelfde die onder de missi wordt vermeld, en die graaf van Artesië was ( ${ }^{2}$ ). Ingelram's graafschappen waren dus niet die, welke bij name worden opgesomd.

Een andere overweging moest trouwens tot hetzelfde besluit brengen : Het komt onaannemelijk voor dat Ingelram tevens meester zou zijn over vijf belangrijke en uitgestrekte gouwen.

De "graafschappen van Ingelram en van Waltcaud" zijn dus de pagi van missaticum III, die niet bij name worden genoemd, nml. Aardenburg, Waas, Gent, Doornik, Oosterbant, Pevele, Melantois, Caribant $\left(^{3}\right)$. Het valt onmiddelijk op, dat deze gebieden twee wel onderscheiden groepen vormen : Gent, Aardenburg en Waas maken het Noord-Oosten van Vlaanderen uit; Doornik, Ostrevant, Pevele, Melantois, Caribant het Zuid-Oostelijke deel. Tusschenbeide ligt de Kortrijker gouw die aan een anderen graaf toebehoorde $\left({ }^{4}\right)$.

(1) Betreffende Sproemberg's voorstelling, zie Ganshof, Les origines $d u$ comte de Flandre " (R. B. P. H., d. XVI, 1937, blz. 367-385), blz. 369-371.

(2) Cf. over hem, Grierson, La maison d'Evrard de Frioul et les origines du comté de Flandre (REvue DU Nord, d. XXIV, 1938, blz. 241-267), blz. 249-50.

(3) Mempiscus, dat ook in het bisdom Doornik lag, uitgesloten, vermits het waarschijnlijk met Iseretius samengesmolten, bij missaticum IV behoorde. Ook al was dit niet zoo, dan toch zou het niet tot Ingelram en Waltcaud, doch tot Berengarius behooren (cf. blz. 556).

(4) Men zou hiertegen misschien willen aanvoeren, dat Doorniker en 
Wie, van Ingelram of Waltcaud, heerschte over den belangrijksten, zuidelijken groep? Het is duidelijk genoeg dat het Ingelram zijn moet, vermits hij abt van Maroilles in Henegouwen was ( $\left.{ }^{1}\right)$ en leenen bezat in deze gouw zoowel als in deze van Laon (2). Daarenboven blijkt hij ook - al heeft hij in 853 nog misschien al zijn invloed op den koning niet verworven - toch 'n heel wat belangrijker personnage te zijn dan de totaal onbekende Waltcaud, die dus beter geeigend schijnt om de kleine en arme gouwen van Waas en Aardenburg, benevens het graafschap Gent, te besturen $\left({ }^{3}\right)$. Totdaar voor missaticum III.

Laten we nu bepalen welke de gouwgraven waren van missaticum IV. De rijksverordening noemt de volgende heeren op : Berengarius, Gerardus, Engischalk en Renier. De drie eersten bezaten elk één gouw, de laatste twee ( ${ }^{4}$ ).

In 846 had graaf Berengarius van koning Karel goederen verkregen, gelegen in pago Mempisco ( $\left.{ }^{5}\right)$. Het is gebruikelijk dat de koning een gouwgraaf met fiscaal goed uit de betrokken gouw begiftigt, zoodat Berengarius vrij waarschijnlijk graaf was van de gouw Mempiscus-Iseretius.

Graaf Gerard blijkt de "villa " Eperlecques ( $\left.{ }^{6}\right)$, in het Terwaansche, te hebben bezeten ( $\left.{ }^{7}\right)$. Hij was dus vermoedelijk

Kortrijkergouw, die onder Lodewijk den Vrome één omschrijving uitmaakten, dit in 853 nog kunnen. Dit gaat echter niet op : het is de Doornikergouw die onder keizer Lodewijk den pagus Cortracensis heeft opgeslorpt. Het bij name vermelden van deze laatste gouw in 853 bewijst dat zulks niet meer het geval is, dat de Kortrijkergouw dus weer als zelfstandige pagus bestaat.

(1) AA. SS. Belg., b. IV, blz. 124.

(2) Ibid.

(3) Hiertegen zal men misschien aanvoeren dat Ingelram abt was van Sint-Pieters te Gent. Grierson heeft echter bewezen (The translation of the relics of St. Amalberga, blz. 308-9) dat zulks niet het geval was.

(4) Zie hooger, blz. 553, n.

(5) Halkin (J.) et Roland (C.), Recueil des chartes de l'abbaye de Stavelot-Malmédy (Brussel, 1909), blz. 78. Het geldt feitelijk goederen in den vroegeren pagus Iseretius gelegen.

(6) Pas de Calais, arr. Saint-Omer, canton Ardres.

(7) Vita Winnoci prior (M. G. H. SS. XV-2, blz. 776) ; Gerardus quidam 
de opvolger van graaf Unrocus van Ternois die vanaf 839 minstens tot vóór 5 september 853 het ambt waarnam (1).

Blijven nog over, Boulogne eenerzijds, Escrebieu en Leticus anderzijds, waarvan één toebehoort aan graaf Engischalk en twee aan graaf Reinier. Dat de eerste Boulonnais moet houden, blijkt uit twee feiten : eenerzijds ligt het voor de hand dat de twee samengelegen gouwen Escrebieu en Leticus aan éénzelfden graaf zouden toebehooren, in casu dus natuurlijk Renier. Anderzijds wordt een capitularium van 857, waarin op de noodlottige gevolgen van de invallen der Noormannen wordt gewezen, gericht "Hunfrido venerabili episcopo (van Terwaan) Ingiscalco et Berengario comitibus et ministerialibus ac fidelibus missis nostris $\left({ }^{2}\right)$. Deze aanduiding slaat natuurlijk op een graaf, die een bij Mempiscus gelegen gebied beheerde vermits hij in één adem met Berengarius wordt genoemd en op een graaf uit de kuststreek, vermits hij bijzonder wordt gewezen op de ellende teweeggebracht door het optreden van de zeeroovers.

Het was wellicht dezelfde Renier, graaf van Escrebieu en Leticus, die bij de troonsbeklimming van Karel den Kale, de cella van Torhout $\left({ }^{3}\right)$, die waarschijnlijk in Vlaandergouw lag, verkreeg; was hij misschien tevens graaf van dezen pagus?

Laten we eenige bijzonderheden over de graven, die over Karolingisch Vlaanderen hebben geheerscht, opzoeken. Over Waltcaud valt niet veel te zeggen : niets is over hem geweten. Hoogstens bestaat een zwak vermoeden dat hij tot een Lotharingisch geslacht behoorde, daar een Waltcaud ten tijde van Karel den Groote, bisschop was te Luik ( $\left.{ }^{4}\right)$. Een andere Waltcaud, mogelijk ook een verwante van den graaf van Gent, wordt in 806 te Aken op een hofdag aangetroffen ( $\left.{ }^{5}\right)$.

comitatum gerens, Deo sancloque Winnoco adeo erat devotus, ut... cum omni namque integritate Spirliacum villam ei dedit".

(1) Grierson, Evrard de Frioul, blz. 243.

(2) Boretius-Krause, Capit. II, blz. 286.

(3) Vita S. Anskarii, c. 21 (Uitg. Waitz -- Hannover, 1884 -, pp. 46, 47). Zie verder blz. 561 .

(4) Cf. Ernhard, Vila Caroli c. 33. Hij was bisschop in de jaren 810-36.

(5) Mühlbacher. DD. Karoli Magni (Hannover, 1906), $\mathbf{n}^{\mathbf{r}} 204$. 
Het schitterende figuur van Ingelram, daarentegen, is te goed bekend ( ${ }^{1}$ ) opdat wij zijn loopbaan hier weer eens zouden navertellen. Laten we er ons toe beperken te zeggen dat hij kamerheer en gunsteling van Karel den Kale werd, en in 870$871\left({ }^{2}\right)$ in ongenade viel $\left({ }^{3}\right)$.

Ook Odelricus is een vrij goed gekend personnage geworden, sedert de opzoekingen van Grierson $\left({ }^{4}\right)$, al schijnt deze geleerde niet te hebben opgemerkt dat Odelricus een neef (nepos) was van Evrard van Frioul (5). Hij wordt in 839 als vassus dominicus vermeld ( $\left.{ }^{6}\right)$. In 846 verschijnt hij onder de getrouwen van keizer Lotharius in het "Capitularium contra Sarracenos" ("), wat bewijst, dat hij zooals vele andere grooten uit het grensgebied, en namelijk Ingelram en Gerardus, die daar met hem worden genoemd, tevens beneficia hield van Lotharius en van Karel. In 853 wordt hij, zooals reeds gezegd, in het capitularium van Servais geciteerd als graaf van Noyonnais, Vermandois, Artois, Kortrijkergouw of Vlaandergouw.

Daar het later blijkt dat hij graaf van Artois is, mag gerust worden aanvaard dat het deze gouw is, welke hij in 853

(1) Zie over hem VANDER KINDERE, Le capitulaire de Servais et les origines du comté de Flandre (B. C. R. H. 5 reeks, d. 7, 1897, blz. 91-138), blz. 101-103.

(2) Over den datum, cfr. Grierson, The Translation of the relics of $\boldsymbol{S t}$. Amalberga, blz. 309, n. 4.

(3) Betreffende de bijzonderheden door Sproemberg (Die Entstehung der Grafschaft Flandern, Berlijn 1935), over Ingelram's loopbaan gegeven, cf. F. L. Ganshof Les origines du Comté de Flandre blz. 376-379.

(4) Cf. La maison d'Evrard de Frioul, blz. 249-250.

(5) Cf. De Coussemaker, Cartulaire de Cysoing, (Lille 1883), $n^{\mathrm{r}} 1$.

(6) R. H. F., VI, blz. 301 : * Ex gestis Aldrici episcopi Cenommanensis •. Diploma van Lodewijk den Vrome onderteekend door Odorricus, vassus dominicus. Betere uitgave - die ik niet kon inzien - door R. Chardes en L. Froger, Gesta Aldrici (Mamers, 1889), blz. 153 of dit diploma vervalscht is - wat soms wordt beweerd - doet weinig ter zake, daar het bewaard wordt in een handschrift van de $\mathrm{Ix}^{\mathrm{e}}$ eeuw en de interpolaties dus in ieder geval historische waarde hebben. De identificatie Odorricus =Odolric, graaf van Artois, is slechts hypothetisch, Zie echter volgende blz. in fine.

(7) G. Grierson, op. cit., blz. 250. 
bestuurde. Hij onderteekent in 858 den eed van Kiersy (1), verschijnt in $863\left({ }^{2}\right)$ en wordt in 866 gelast met het opstellen van het polypticum van Sint-Vedast $\left({ }^{3}\right)$. Na de ongenade van Ingelram krijgt hij een deel van dezes bezittingen en onderteekent in 874, als graaf van Oosterbant, een oorkonde van Gisela, weduwe van markgraaf Everardus van Frioul (4). Ook Melantois, een ander van Ingelram's gouwen, had hij weten in handen te krijgen ( ${ }^{(5)}$. Hij schijnt tot minstens 877 zijn gezag te hebben bewaard $\left(^{6}\right)$. Over de overige graven die hun gouwen in missaticum III, d. i. bisdom Noyon-Doornik, hebben, is niets geweten. Wel wordt meestal aanvaard dal Vermandois van den tijd van Lodewijk den Vrome af, in handen is van de afstammelingen van Bernardus, koning van Italie, nml. zijn zoon Pepijn of zijn kleinzoon Herbrecht de Ie, die in 896 tijdelijk van dat graafschap wordt beroofd door Boudewijn den IIe. Maar bepaalde bewijzen worden daarvoor niet aangevoerd ( $\left.{ }^{(}\right)$.

Nu komen de graven van missaticum IV, d. i. in hoofdzaak, het bisdom Terwaan, aan de beurt.

Renier, die we voor den graaf van Leticus, Scarbeius, en misschien Vlaandergouw aanzien daagt op in 839, in een diploma van Lodewijk den Vrome, waarin hij "vassus dominicus " wordt bestempeld ( $\left.{ }^{8}\right)$. Het is merkwaardig dat datzelfde stuk ook de namen vermeld van Odelric, de graaf van Artois, en van Letricus, d. i. Liederik $\left(^{(}\right)$.

(1) Ibid.

(2) R. H. F., VIII, blz. 588-89.

(3) Cf. Grierson, loc. cit.

(4) Ibid.

(5) Ibid.

(6) Ibid.

(7) Zie over hem, Ph. Grierson, L'origine des comtes d'Amiens, Valois et Vexin (Le Moyen AGe, 1939), p. 11 van den overdruk, n. 50. Lemaire (E.), Histoire de Saint-Quentin, MÉm. DE LA soc. DE SAINT-Quents, IV reeks, d. 8, blz. 266-69, schijnt echter wel te bewijzen dat Vermandois niet voor 889 aan de afstammelingen van koning Bernardus ten deel viel.

(8) Zie tekst vermeld in $n .6$, blz. 558 hierboven.

(9) Daar de Liederik die te Harelbeke zou zijn te ruste gelegd, in 836 
Om het geslacht te bepalen waartoe Reinier behoorde, mag niet uit het oog worden verloren dat ten tijde van Lodewijk den Vrome, West-Francië en Lotharingen tot éénzelfde rijk behoorden, en dat de graven toen uiteraard zeer gemakkelijk van ambtsgebied wisselden, zooals Poupardin terecht doet opmerken ( $\left.{ }^{(}\right)$Een andere voorafgaande opmerking dient gemaakt, en wel, dat de naam Reinier allesbehalve verspreid is in de negende eeuw, zooals men zou geneigd zijn te gelooven, wanneer men zich laat verblinden door het veelvuldig verschijnen van dezen naam bij de latere Lotharingische geslachten.

Daarop steunende mag men de hypothese vooropstellen, dat onze graaf behoort tot het huis, waarin deze naam erfelijk bleef, d. w. z. de dynastie van Renier Lankhals. Deze laatste was de zoon van Gijselbrecht, graaf van de Maasgouw, en van een dochter van Lotharius den Eerste.

Ten tijde van Lotharius den Tweede en van graaf Gijselbrecht van de Maasgouw, behoort de abdij Echternach - later een familiegoed van het geslacht van Renier Lankhals - herhaaldelijk toe aan, een Reginarius ( $\left.{ }^{2}\right)$. Andere dragers van dien naam zijn in dezen tijd onbekend ( $\left.{ }^{3}\right)$. Dat de Renier, die tijdens de regeering van Gijselbrecht van de Maasgouw te Echternach optreedt zeer waarschijnlijk een verwante, ja, vermoedelijk een broer van Gijselbrecht is, zal niemand betwisten. Dat hij ook dezelfde weze als zijn eenige bekende naamgenoot, nml. de graaf van Leticus, is natuurlijk een louter hypothese, doch geen al te gewaagde hypothese, dunkt ons?

is gestorven, kan de hier vermelde Liederik, indien hij iets met Vlaanderen uitstaans heeft, slechts zijn zoon zijn.

(1) Le royaume de Provence sous les Carolingiens (Parijs, 1903). App. Les grandes familles comtales à l'époque Carolingienne, p. 384: « Les comtes sont d'ailleurs essentiellement amovibles et passent sans difficulté de la Gascogne au Parisis,.. des bouches de l'Elbe à la marche de Frioul ".

(2) Parisot, Le royaume de Lorraine (Parijs, 1898), blz. 331, n. 5, blz. 542 , n.

(3) De zeer volledige lijst van de Reniers welke door Chaume (Les Origines du duché de Bourgogne, I (Dijon, 1925), blz.549, wordt gegeven omvat : $1^{\circ}$ " Renier comte de Mempiscus ; $2^{\circ}$ Renier $(\dagger 876)$ abbé d'Echternach, 864870 ; $3^{\circ}$ Renier, comte, 877-886. We vereenzelvigen de 2 eerste Reniers. 
Renier die in 838 zooals gezegd, voor het eerst wordt aangetroffen, was dus, een aanhanger van Karel den Kale, die hem, dadelijk na den dood van Lodewijk den Vrome, met de kleine abdij Torhout begiftigde. (1) Lang daarna, doch vóór juni $862\left({ }^{2}\right)$ viel hij in ongenade. Tusschen 864 en 870 verschijnt de abt Renier van Echternach ( $\left.{ }^{3}\right)$. Is het niet de verbannen graaf van Vlaandergouw die, dank zij de steun van zijn broeder Gijselbrecht, deze vergoeding van Lotharius heeft verkregen? Hij werd vermoedelijk van dat beneficium beroofd toen Lodewijk de Duitscher na het verdrag van Meersen, de hand legde op dat deel van Lotharius' rijk. Dit zal wel de reden zijn die Reginarius weer tot de partij van den Franschen koning deed overhellen; hij sneuvelde immers in Karel's dienst, in den slag te Andernach, anno $876\left({ }^{4}\right)$.

Thans gaan we het over Gerardus hebben. Ten tijde van Karel den Kale worden drie Gerardus' aangetroffen (5). Een van hen, die uitsluitend in Zuid-Frankrijk optreedt, mag hier onbesproken worden gelaten $\left({ }^{6}\right)$. Een tweede, de beroemde Gerard de Roussillon, is niet zoo aanstonds voorbij te gaan. Wel speelt zijn rol zich vooral af in Burgondie, waar hij optreedt als fidelis van keizer Lotharius, doch het eerste wat we van zijn loopbaan vernemen is dat hij als graaf van Parijs, optreedt met de heeren van "Tusschen Kolenwoud en Seine" ( $\left.{ }^{7}\right)$, wat

(1) Vita Anskarii, c. 21 (uitg. Wartz, blz. 46, 47).

(2) Ibid.: "Nam multo post, iram regis meruit, et cellam ipsam cum omnibus quae ex parte regis habebat, perdidit, nec ulterius in pristinam gratiam redire potuit". Dit werd geschreven kort na 865 (cf. DE MOREAU, Saint Anschaire - Leuven, 1930 - blz. 131, n. 10). Op 2 juni 862 beschikt Karel de Kale over de cella (Wauxers, Tables Chronol., I, blz. 245). De ongenade van Renier valt dus voor dat oogenblik en duurde minstens tot 865 .

(3) Parisot, op. cit., blz. 542, n.

(4) Annales Bertiniani, uitg. Wartz, blz. 133.

(5) Cf. Poupardin, Le royaume de Provence, blz. 295 vlgg. "Les comtes Girard sous Charles le Chauve".

(6) Ibid.

(7) Nithard, uitg. Lauer, blz. II, c. 3, 44 ; II, c. 6, blz. 54, 56 : "Cumque Sequanam venisset (rex) repperit Guntboldum, Warnarium, Arnulfum, Gerardum necnon et omnes a Carbonariis et infra comites, abbates, episcopos ". 
dus wel op verband met den graaf van Ternois zou kunnen wijzen. Een ander feit is nog geschikt om identificatie tusschen graaf Gerardus en Girard de Roussillon in de hand te werken : de hardnekkige legende die Girard met Henegouwen en Vlaanderen verbindt ( $\left.{ }^{(}\right)$.

Wat o. i. nochtans de identificatie beslissend tegenspreekt, is dat graaf Gerardus van Ternois zijn ambt blijkbaar nog vervult in $863\left({ }^{2}\right)$, d. i. op een oogenblik waarop Girard de Roussillon reeds lang in Zuid-Frankrijk werkzaam is.

Gerard van Ternois schijnt dan de derde in dien tijd bekenden graaf van dezen naam te moeten zijn, dczc waarvan de loopbaan kennelijk West-Frankisch en Lotharingisch is georienteerd: hij zou tot de dynastie behooren waarin de namen Gerard en Matfried telkens terugkomen, en die afstamde van Matfried, graaf van Orléans ten tijde van Lodewijk den Vrome ( $\left.{ }^{8}\right)$; Gerardus van Ternois ( \pm 853 -vóór 866) zou dan, schijnt het, een zoon van dezen eersten Matfried zijn en derhalve een broer van den gelijknamigen graaf die onder Lotharius den Tweede, graaf was van de Eifelgouw ( $\left.{ }^{(}\right)$.

Al deze - onmiskenbaar broze - genealogie daargelaten, schijnt onze Gerardus te worden bedoeld in het $\mathrm{Ca}$ pitularium Contra Sarracenos van keizer Lotharius (846), waarin ook Odolricus, graaf van Artois, en Ingelrammus, graaf van Doornik, Oosterbant, e. a. worden geciteerd (5). Zooals reeds gezegd, was hij eigenaar van Eperlecques in Ternois, dat hij aan de abdij Wormhout afstond. Hij schijnt in 863 nog zijn graafschap te bezitten, vermits hij in dat jaar, samen met zijn naburen, de graven Odelric en Berengarius, in een koninklijk diploma voor de kerk van Rouen wordt vermeld ( $\left.{ }^{(}\right)$. In 866 verschijnt Vuitmar als graaf van Ternois ( $\left.{ }^{7}\right)$.

(1) Cf. Boenen (P. C.), De oorsprong van Limburg en Gelre (Maastricht, 1938), blz. 126-128.

(2) R. H. F., VIII, blz. 588-89.

(3) Parusot, op. cit., blz. 500-501.

(4) Ibid.

(5) Boretius-Krause, Capitularia, II, blz. 68.

(6) R. H. F., VIII, blz. 588-89.

(7) Gukrard, Cartulaire de Saint-Bertin, blz. 167. 
Wat is er met Gerardus gebeurd? Het is niet geweten, doch hij blijkt tot 877 te hebben voortgeleefd ( $\left.{ }^{1}\right)$.

Over Engischalk is er niets te zeggen : in 857 wordt hij in verband met onze gewesten nog eens vermeld $\left({ }^{2}\right)$ en in 859 wordt zijn naam weer in een capitularium aangetroffen (8). Wat Adalgarius betreft, zijn naam komt vrij dikwijls voor in de bronnen, doch zijn rol is niet duidelijk. Abt Adalard's loopbaan werd door Grierson voortreffelijk bestudeerd ( $\left.{ }^{4}\right)$.

Tenslotte een woord over Berengarius. Een Berengar verschijnt in 825 als missus in de bisdommen Noyon, Terwaan, Amiens en Kamerijk (5). Hij kan dezelfde zijn als de Berengarius aan wie Gebhard voor vader wordt toegeschreven ( ${ }^{6}$ ), want beiden treden gelijktijdig op in dezelfde streek : Berengarius Gebhardszoon hield leenen in Lotharingen en onze Berengar stond in nauwe betrekkingen met dat gebied, ja, was er zeer waarschijnlijk uit afkomstig. Inderdaad : uit een oorkonde verneemt men dat koning Karel hem in 846 " honores" " in pago Mempisco " heeft geschonken. Welnu, dat document (") is ons slechts bewaard in het cartularium van Stavelot-Malmedy. Dit onderstelt dat het betrokken goed door Berengarius zelf, of door een zijner nauwste erfgenamen - lang zou het charter in leeke handen niet zijn bewaard gebleven ( $\left.{ }^{8}\right)$, - deze bezittingen aan de vermelde abdij heeft afgestaan, wat weer veronderstelt dat deze graaf of zijn geslacht in nauwe betrekkingen stonden met Stavelot-Malmedy.

Onder de "fideles missi " van Karel den Kale wordt Berengar

(1) Poupardin, loc. cit.

(2) Boretius-Krause, Capitularia, II, blz. 286 : "Hunfrido venerabili episcopo, Ingiscalco et Berengario comitibus et ministerialibus ac fidelibus missis nostris *.

(3) Ibid., blz. 205.

(4) Evrard de Frioul, blz. 243-245.

(5) Boretrus, Capitularia, I, blz. 308.

(6) Parisot, op. cit., blz. 137.

(7) Halkin (J.) en Roland (C.), Recueil des chartes de l'abbaye de Stavelot-Malmédy (Brussel, 1909), blz. 78.

(8) Het geschonken goed wordt nergens elders vermeld in het archief van de abdij en is dus zeer spoedig verloren gegaan. 
in 856 driemaal vermeld (1) en in 857 wordt hij kennelijk in verband met zijn gezag in Vlaanderen, geciteerd ( $\left.{ }^{2}\right)$. In 863 wordt hij, met de naburige graven Gerardus en Odelricus, voor het laatst aangetroffen ( ${ }^{3}$ ). Zijn ambtsuitoefening schijnt zich dus minstens tusschen de jaren $846-863$ te situeeren ( $\left.{ }^{4}\right)$.

\section{De Kustverdediging van Vlaanderen.}

Door haar ligging aan de monding van breede en diepe stroomen, tegenover Engeland, door haar vlakke, destijds ingesneden kust, was Vlaanderen voorbestemd om handel en verkeer te doen bloeien.Dit is ook gebeurd. Parallel met de zoozeer geroemde economische ontwikkeling van de Maasvallei ontluikte langs de oevers van de Schelde een handelsbedrijvigheid die tot een reeks portussen ontstaan gaf : Gent $\left({ }^{5}\right)$,

(1) Boretius-Krause, op. cit., II, blz. 279, 283, 284.

(2) Zie hooger blz. 563, n. 2, den tekst betreffende Ingischalk.

(3) R. H. F., VIII, blz. 588-89.

(4) Een ander Berengarius, een zeer aanzienlijk personnage, die eigenlijk wel dezelfde zijn kan als onze Berengarius, verschijnt tegelijkertijd Hij was gehuwd met Helletrudis, een dochter van keizer Lotharius, en wordt onder de vertegenwoordigers van Lotharius den II' genoemd op het Koblentzer verzoeningsverdrag (Boretrus-KraUse, op. cit., II, blz. 154). Tengevolge van een opstand - of hij daaraan werkelijk med eplich tig was, wordt niet uitdrukkelijk gezegd - wordt hij door Lotharius, op aanzetten van Lodewijk den Duitscher, verbannen (Ann. Bertiniani, uitg. WaItz, anno 861, blz. 55). Hij vlucht naar West-Francie. Omwille van zijn zwakke houding in den strijd tegen de Noormannen, - althans dat gaf koning Karel voor - werd hij in 865 weer van zijn leenen beroofd (ibid., anno 865 . blz. 80) en stierf kort daarop, want in een brief van paus Nikolaas aan Karel den Kale (R. H. F., VII, blz. 438) die door de uitgevers circa 866-867 wordt gedagteekend, wordt van Berengarius gesproken als van iemand die niet lang geleden gestorven is. Uit dezen brief is het dat we vernemen dat bedoelde graaf met Lotharius' dochter was gehuwd. In 882 wordt een graaf Hildebertus vermeld, die mogelijk ook tot het geslacht van onzen Berengarius behoort, ja vermoedelijk zijn zoon is : immers wijlen Hildebert's vader, en zijn eigen broer, heetten Berengarius (PArisot, op. cit., blz. 764-65). VANDER Kindere heeft waarschijnlijk gemaakt dat dit graven zijn van Ivois aan de Maas (Formation Territoriale II, blz. 339.

(5) Over het Karolingisch portus van Gent, cf. J. Blockmans a De twee 
Doornik (1), Valençijn ( $\left.{ }^{2}\right)$, Kamerijk $\left({ }^{3}\right)$, Lambres bij Dowaai, op de Scarpe (4). En, eigenaardig genoeg, deze nederzettingen ontstaan altijd naast fisci, alsof de handelaars wilden genieten van de koninklijke bescherming die eruit straalde (5).Benevens deze binnenhavens ontstonden hier ook zeehavens: Quentovic $\left({ }^{6}\right)$, een der belangrijkste Karolingische havens, Boulogne, een krijgsvlootbasis die dan ook wel koopvaardijhaven zal zijn geweest( $\left.{ }^{7}\right)$, Isere portus, een haven aan de IJzermonding $\left(^{8}\right)$ ! Vlaanderen was dus, uit economisch oogpunt, een bloeiende, rijke streek.

Maar daaraan waren nadeelen verbonden! De rijkdom van het land, zijn geschikte aanlegplaatsen, zijn goed bevaarbare stroomen waren van aard om niet alleen vreedzame handelslui, echter ook zeeroovers aan te lokken,'t zij ze een vluggen voordeeligen strooptocht wilden ondernemen in een rijk ge-

opvolgende Gentsche "portus " (Handelingen van het Genootschap "Socrété D'Émulation ", d. LXXXII, blz. 52-83).

(1) Over Doornik in den Karolingischen tijd, cf. F. Vercauteren, Etude sur les Civitates de la Belgique seconde (Brussel, 1934), blz. 246-248.

(2) Valençijn wordt in het Martyrologium Usuardi (AA. SS. Boll., Juni, VI, blz. 153) "vicus " genaamd. De daar geslagen Karolingische munten dragen het opschrift "Valencianas port" (Prou, Catalogue des monnaies franfaises de la Bibliotheque Nationale. Les monnaies carolingiennes. Parijs, 1896, blz. 33, $\mathrm{n}^{\mathrm{r}}$ 208-211.)

(3) Gf. Vercauteren, op. cit., blz. 212-214.

(4) Gesta episcoporum Cameracensium, M. G. H. SS. VII, blz. 460 *apud Lambres... erat enim regius fiscus... illo etiam tempore portus illuc habebatur ".

(5) Over de fisci te Gent, cf. hooger, blz. 549. Over dezen van Doornik, zie blz.550. Over den fiscus van Valençijn, cfr. hooger blz. 551. Er was te Kamerijk een koninklijk palatium, cf. Vercauteren, op. cit., blz. 209-210. Voor Lambres tenslotte, zie vorige noot.

(6) Cf. Fengler (O.), Quentovic, seine maritime Bedeutung unter Merovingern und Karolingern (HANsische GeschichtsBlätTer, d. XIII, 1907).

(7) Bononiam civitatem maritimam (Annales Regni Francorum, anno 811 (uitg. Kurze, blz. 135). Civitas beteekent niet uitsluitend bisschoppelijke stad, In Vlaanderen worden in de $1 x^{\circ}$ eeuw Kortrijk, Aardenburg en Antwerpen zoo genoemd. Dit is ook het geval met Dinant.

(8) Miracula sancti Bertini, geschreven om 890 (M. G. H. SS. XV, 1, blz. 509) : "in finibus Menapum, sinum quod vocatur Iserae portus *. 
west, 't zij ze een weg zochten om tot het hart van Frankrijk door te dringen.

Zoo kwam het, dat wanneer circa 800 de Scandinaviërs, onder den drang van hun steeds toenemende bevolking, op verre rooftochten uitgingen, onze landstreek spoedig het geliefkoosde doel van hun reis werd.

In 800 verneemt men voor het eerst, dat de Noordzee door de "piratis" onveilig wordt gemaakt (1). Voortaan komen verhalen en verslagen van plundertochten en invallen der Noormannen als een droevig refrein voor in de kronijken en jaarboeken van Frankrijk en Lotharingen (2).

Karel de Groote heeft echter op krachtige wijze gereageerd op deze bedreiging : in 800 vaart hij over de Noordzee van de Rijnmonding tot in Ponthieu en plaatst garnizoenen en afdeelingen van de vloot langs de kust $\left({ }^{3}\right)$; hij roept dus blijkbaar een bestendige verdedigingsorganisatie van de kusten in het leven.

Herhaaldelijk wordt daarvan gewaagd : een verordening van 802, die de missi van Parijs, Rouen en Orléans betreft, verstrekt gegevens over deze inrichting : het capitularium bepaalt dat ieder vrij man, letus of servus uit de "maritima loca", op straf van een zware boete, verplicht is, zoodra hij daartoe wordt gemaand, mee te helpen tot de verdediging van de "littoralia maris" (4) latere teksten gewagen ook van de "co-

(1) Annales Regni Francorum, anno 800 (uitg. Kunze, blz. 110) : Rex medio mense martio Aquisgrani palatio digrediens, litus oceani gallici perlustravit, in ipso mari quod tunc piratis infestus erat, classem instituit, praesidia disposuit, pascha in Centulo... celebravit.

(2) Ze werden op merkwaardige wijze bestudeerd door W. VoakL, Die Normannen und das Frankische Reich (Heidelberg, 1906).

(3) Zie hooger, n. 1.

(4) Bonetius, Capitularia, I, blz. 100, Capitulare missorum specialia, c. 13a: - De navigia praeparanda circa littoralia maris ", c. 13b. De liberis hominibus qui circa maritima loca habitant, si nuntius venerit, ut ad succurendum debeant venire, et hoc neglexerint, unusquisque solidos viginti componat, mediaetatem in dominico, medietatem ad populum. Si litus fuerit, solidos quindecim conponat ad populum et fredo dominico in dorso accipiat; Si servus fuerit, solidos decem ad populum et fredo dorsum .. 
mites qui ad custodiam maritimam deputati sunt "(1).

Hierdoor krijgen we voldoende inzicht in de instelling : de kusten werden verdedigd door de samenwerking van de ingezetenen der betrokken pagi — vrije zoowel als half en onvrijen - met de bestendige garnizoenen en smaldeelen, aangevoerd door bijzondere comites. De tekst uit de Annales Regni Francorum van het jaar 800 leerde ons reeds, dat het de noordzeekust is, die derwijze werd ingericht. Betreft dit ook de kustpagi van het latere vorstendom Vlaanderen, Vlaandergouw, Mempiscus-Iseretius en Boulogne?

Dit is vanzelfsprekend ! Indien de keizer immers de kust van het. rijk organiseert tegen de Noormannen, zal hij wel geen hiaat in dat defensief stelsel hebben gelaten, en dan nog wel op een der meest toegankelijke en bedreigde plekken ! Einhard, de bekende biograaf van Karel den Groote, spreekt trouwens duidelijke taal : hij weet te vertellen dat zijn held schepen, bestemd om de Noormannen te bevechten, liet bouwen langs alle stroomen van Germanië en Gallië die zich in de Noordzee werpen ( ${ }^{2}$ ). Immers, zegt hij verder, daar de Noormannen de kusten van Gallië en Germanië teisterden, plaatste Karel garnizoenen en schepen aan alle mondingen van bevaarbare stroomen $\left({ }^{3}\right)$.

Deze uitlatingen laten aan duidelijkheid niets te wenschen

(1) Capitulare missorum, Boretus, op. cit., blz. 301, anno 821 : comites, qui ad custodiam maritimam deputảti sunt *; zie ook nog over deze marke Capitulare Bononiense, 811 (ibid., blz. 167) : c. 11. Ut quandocumque navigium mittere volumus, ipsi seniores in ipsis navibus pergant, et ad hoc sint praeparati *. Ook ibid., blz. 139 (808): "De navibus quas facere jussimus; de marcha nostra custodienda terra marique ". Cf. ook Chronicon Moissiacense (M. G. H. SS, I, blz. 311) : "Ludovicus... praesidia posuit in litore maris ubi necesse fuit ".

(2) Vita Caroli, c. 17 : "Molitus est et classem contra bellum Nordmannicum, aedificatis ad hoc navibus juxta flumina quae et de Gallia et de Germania septentrionalem influunt oceanum... .

(3) Ibid., "et quia Nordmanni Gallicum litus atque Germanicum adsidua infestatione vastabant, per omnes portus et ostia fluminum qua naves recipi posse videbantur stationibus et excubiis dispositis, ne qua hostis exire potuisset tali munitione prohibuit *. 
over : de keizer wil de plunderaars verhinderen aan wal te komen, door de aanlegplaatsen en de mondingen van de stroomen te versterken. Dit onderstelt weer, dat de organisatie de gansche kust gold, en daarover kan trouwens géén twijfel opgaan: Eginhard bepaalt dat het de Noordzeekusten van Gallië en Germanië waren, die bedreigd werden. Welnu, wat kan Noordzeekust van Gallië beteekenen, vooral wanneer het in één adem met "Germanië " wordt genoemd, tenzij juist de kustgouwen van het latere Vlaanderen?

Met gezond verstand vertaald, beduiden de woorden van Einhard dus, dat Karel de Groote de Vlaamsche kust van garnizoenen heeft voorzien, aan de havens van onze kust en aan de mondingen van onze stroomen, d. w. z. Schelde, IJzer, Aa en Canche, een afdeeling van de vloot en bestendige posten heeft geplaatst.

Dit kan trouwens door teksten worden bewezen, voor de monding van de Canche, voor Boulogne en voor den pagus Flandrensis.

Te Quentovic, aan de monding van de Canche, wordt het bewind uitgeoefend door een zekeren Grippo "dux " $\left({ }^{1}\right)$, wat in de negende eeuw voor West-Francië overeenstemt met markgraaf ( ${ }^{2}$ ). Te Boonen lag de vloot, bestemd om de Noormannen te bevechten, geankerd. Karel de Groote had in 810 bevolen schepen te bouwen en kwam ze daar in 811 schouwen( $\left.{ }^{3}\right)$.

(1) Miracula S. Wandregisill (M. G. H. SS., XV, 1, blz. 408-9. Gripo prefectus videlicet emporii Quentovici... prefatus dux.... dux.....

(2) Robrecht de Dappere, " markgraaf " (Annales Bertiniani, anno 865, uitg. WaItz, blz. 79) wordt ook "dux" genoemd (Annales Xantenses, anno 866, uitg. de Simson, blz. 25 en Adrevald, Miracula Sancti Benedicti, 1, I, c. 3, uitg. de Certain, blz. 71).

(3) Annales Regni Francorum (uitg. KURze, blz. 135), anno 811 : "Ipse (de keizer) autem interea propter classem, quam anno superiore fieri imperavit, videndam, ad Bononiam civitatem maritimam, ubi eaedem naves congregate erant, accessit, farumque ibi ad navigantium cursus dirigendos antiquitus constitutam restauravit...; inde ad Scaldim fluvium veniens in loco, qui Gand vocatur, naves ad eandem classem aedificatas aspexit et circa medium Novembrium Aquas venit *. Het was bij gelegenheid van zijn verblijf te Boonen, dat de keizer het capitulare Bononiense gaf, waarin 
Hij gaf tevens bevel een vuurtoren op te richten, wat bewijst dat deze haven de bestendige basis was van het eskader (1).

Toen de Noormannen in 820 trachten te landen " in littore Flandrensi " werden ze teruggedreven " $a b$ his qui in praesidio erant" (2). In den pagus Flandrensis lag dus een garnizoen.

Er bestaat nog een andere tekst betreffende deze inrichting : de reeds genoemde biograaf van Karel den Groote, Einhard, was tevens leeke abt van Sint-Pieters en Sint-Baafs te Gent ( ${ }^{(3)}$. In deze hoedanigheid schrijft hij circa $834\left({ }^{4}\right)$ aan een keizerlijken missus dat zijn mannen - vermoedelijk de hoorigen van de abdij - ingevolge het bevel van den keizer, aan de kustverdediging hebben deelgenomen $\left({ }^{5}\right)$. Uit het voorgaande blijkt dat Boulogne, de mondingen der Vlaamsche stroomen, de pagus Flandrensis, kortom, gansch de kust van het latere vorstendom Vlaanderen, een bestendige defensieve inrichting bezat tusschen 811 en 832 . Nu dàt feit vaststaat, mag ook gereedelijk worden aanvaard dat zeekantig Vlaanderen reeds in 800 , samen met de overige kusten van de Noordzee, derwijze werd ingericht.

Is deze organisatie na 834 verdwenen? Niets wettigt dat vermoeden. Een passage uit de Annales Bertiniani schijnt wel op onze " custodia maritima" te slaan : in 836, nadat de Noormannen een tocht hadden gedaan die tot Antwerpen reikte ( $\left.{ }^{6}\right)$,

nieuwe bepalingen betreffende de inrichting van de kustverdediging werden afgekondigd (zie hooger, blz. 567, n. 1).

(1) Zie vorige noot.

(2) Annales Regni Francorum (uitg. Kunze, blz. 153), anno 820 : "de Nordmannia vero tredecim piraticae naves egressae, primo in Flandrensi litore praedari molientes ab his, qui in praesidio erant, repulsae sunt... propter custodum incurian aliquot casae viles incensae... In ostio Sequanae similia temptantes, resistentibus sibi litoris custodibus... inritae recesserunt ".

(3) Daarover Ganshof, Eginhard d Gand (Bull. DE LA socréte D'HIsTOIRE ET D'ARchéologie DE GaNd, 1926, blz. 13-33).

(4) Over het dagteekenen van dat document, cf. GaNshof, op. cit., blz. 26, n. 4.

(5) Epistolae aevi Carolini V, Epistolae Einhardi, $\mathrm{n}^{\mathrm{r}} 23$ : "Homines nostri quos in istis partibus habemus, secundum ordinationem et jussionem domni imperatoris ad custodiam maritimam fuerunt *.

(6) Cf. VoGel, op. cit., blz. 70. 
werd de kustverdediging door Lodewijk denVrome heringericht in Friesland en in de "maritima loca" (1). Het is niet meer dan logisch dat, indien het verweer in Friesland wordt ingericht, ook in het vlak daarnaast gelegen Vlaanderen maatregelen worden getroffen, zoodat met "loca maritima", waarschijnlijk onder meer onze kust wordt bedoeld.

Maar de genomen beslissingen baten niet, althans in Friesland, want weer vielen de zeeroovers in het land binnen en weer werd Lodewijk de Vrome tot ingrijpen genoopt. Het gebeuren is belangwekkend genoeg voor de geschiedenis van de kustverdediging om hier te worden vermeld: onverwijld liet de keizer een onderzoek instellen naar het voorgevallene en ondervroeg de heeren, aan wie hij had opgelegd Friesland te verdedigen. Uit het enkwest bleek dat ze hadden gefaald, deels omdat de taak te zwaar was, deels omdat de Friezen ongehoorzaam waren geweest. Tengevolge hiervan werden krachtdadige graven en abten in Friesland aangesteld, en onverwijld werd daarheen een vloot gestuurd $\left({ }^{2}\right)$. In 838 tenslotte deed de keizer een krachtige poging, om de kusten te beveiligen door het herinrichten van de custodia" $\left({ }^{3}\right)$.

Daaruit blijkt duidelijk genoeg, dat de organisatie wel door de burgeroorlogen was ondermijnd, doch bleef voortbestaan en nog altijd hetzelfde aspect bood als ten tijde van Karel den Groote: ze omvatte twee elementen: de ingezetenen zelf, aangevoerd door "krachtdadige graven" en een permanent element, hier de vloot.

Het zal wel door niemand worden betwijfeld, dat de toestand

(1) Ann. Bert., anno 836 (uitg. WaItz, blz. 11), Imperator, Aquis perveniens, disposita omni maritima custodia... ; anno 837 (blz. 13) : Imperator, disposita Frisiae maritimaque custodiam ".

(2) Ibid., blz. 14 : "Imperator vero, generali conventu habito, publice cum his quaestionem habuit, quos principes ad eandem custodiam delegaverat. Qua discussione patuit, partim inpossibilitate, partim quorumdam inoboedientia, eos inimicis non potuisse resistere. Unde et ad comprimendam Frisionum inoboedientiam, strenui abbates ac comites directi sunt. Verum ut deinceps illorum incursionibus facilius obsisti queat, classis quaquaversum diligentius parari jussa est ".

(3) Ibid., blz. 15 : copiosus circa maritima apparatus distributus est *. 
in Vlaanderen toen de trouwe weergave moest zijn van dezen in Friesland: Vlaanderen was minstens even belangrijk als Friesland, de twee gebieden lagen vlak naast elkander, in éénzelfde rijk, en het eene verdedigen zonder het andere ware bepaald ondoeltreffend geweest.

Totdaar voor de regeering van Lodewijk den Vrome.

Zal deze organisatie zijn ten onder gegaan wanneer Karel de Kale in West-Francië aan het bewind kwam? Het kan niet worden verzwegen dat de bronnen hier niet langer uitdrukkelijk zijn en overvloedig, doch daaruit te besluiten dat de inrichting verdwenen is, ware een $o$. $i$. uiterst oppervlakkige beschouwing. Was immers de relatieve ligging van Vlaanderen tegenover Scandinavië veranderd? Neen; was de verdedigingstactiek der Franken tegen de zeeroovers (de "custodia maritima ") opgegeven? Geenszins (1). Was het gezag van Karel in Vlaanderen onvoldoende gevestigd? Ook niet ( ${ }^{2}$ ). Waarom, zou dan de inrichting in Vlaanderen zijn verdwenen?

Het kan nochtans niet worden geloochend, dat deze organisatie allesbehalve doeltreffend werkt: onophoudend vallen de Noormannen in het West-Frankisch rijk - in Lotharingen trouwens ook! - binnen om plundertochten te ondernemen. Maar daaruit moet niet besloten worden tot de ontstentenis van een defensieve organisatie, want in de Loirestreek, waar het bestaan van een marke vast staat $\left({ }^{3}\right)$, zijn dergelijke plundertochten schering en inslag. ( $\left.{ }^{4}\right)$ Men mag dus gerust gelooven dat, wanneer koning Karel in 854 bepaalt : "de maritima custodia, ut secundum consuetudinen vigilanter disponeretur "( $\left.{ }^{5}\right)$ dit ook voor onze kustgouwen geldt, want ook in dat gebied

(1) Zie hierna, n. 5 .

(2) Dit blijkt uit de rijksverordening van Servais, waar voor Vlaanderen maatregelen worden getroffen, evengoed als voor elk ander deel van het rijk.

(3) In 841 wordt daar een Rainaldus als markgraaf aangetroffen (Ann. Bert., blz. 29). In 849 is Lambert markgraaf, in 865 Robrecht de Dappere.

(4) Cf. de berichten uit de Annales Bertiniani voor die jaren.

(5) Boretius-Krause, Capitularia, II, blz. 277. 
zorgt de koning er voor dat rust en vrede heerschen; dit blijkt uit het reeds meermalen besproken capitulare van Servais, dat slechts een jaar ouder is dan de verordening op het herinrichten van de kustverdediging. Daar tenslotte onze gewesten in $850\left({ }^{(}\right), 851\left(^{2}\right)$, en $852\left({ }^{3}\right)$ door de Scandinaviërs werden geplunderd, zou men heelemaal niet begrijpen dat juist hier te lande geen defensieve organisatie zou zijn onderhouden.

Het voortbestaan van de kustverdediging van Karel den Groote en Lodewijk den Vrome onder Karel den Kale mag dus, meenen we, gerust worden verondersteld.

(wordt vervolgd)

\author{
J. DHONDT, \\ Aangesteld Navorscher van het \\ Nationaal Fonds voor \\ Wetenschappelijk Onderzoek.
}

(1) Ann. Bert., blz. 38.

(2) Ibid., blz. 41 (verwoesting van Sint-Baafs te Gent).

(3) Ibid., blz. 42. 